\title{
Mental Torture: A Critique of Erasures in U.S. Law
}

David Luban

Georgetown University Law Center, luband@law.georgetown.edu

Henry Shue

University of Oxford

Georgetown Public Law and Legal Theory Research Paper No. 11-31

This paper can be downloaded free of charge from:

https://scholarship.law.georgetown.edu/facpub/620

http://ssrn.com/abstract=1797806

Geo L.J. (forthcoming)

This open-access article is brought to you by the Georgetown Law Library. Posted with permission of the author. Follow this and additional works at: https://scholarship.law.georgetown.edu/facpub

Part of the Criminal Law Commons, and the International Law Commons 


\title{
MENTAL TORTURE
}

\author{
A Critique of Erasures in U.S. Law \\ David Luban $^{*}$ and Henry Shue ${ }^{* *}$ \\ Forthcoming, GEORGETOWN LAW JOURNAL, vol. 100, no. 3
}

ABSTRACT:

Both international and federal law criminalize mental torture as well as physical torture, and both agree that "severe mental pain or suffering" defines mental torture. However, U.S. law provides a confused and convoluted definition of severe mental pain or suffering - one that falsifies the very concept and makes mental torture nearly impossible to prosecute or repress. Our principal aim is to expose the fallacies that underlie the U.S. definition of mental torture: first, a materialist bias that the physical is more real than the mental; second, a substitution trick that defines mental pain or suffering through a narrow set of causes and effects, ignoring the experience itself; third, a forensic fallacy, in which the due process requirements of specificity in criminal law become wrongly identified with defining characteristics of the crime of torture (an understanding that loops back to corrupt the law); and fourth, a mens rea requirement that excludes all mental torture not committed with the sadistic intention of causing long-lasting harm. Our article begins with an analysis of the concept of mental pain and suffering, as well as a factual discussion of U.S. practice. We also examine the legislative history of the definition in U.S. law. We demonstrate that it derives from political concerns that other countries might accuse U.S. law enforcement personnel of torture. We conclude by examining the specific evil of mental torture: the merciless attempt to break down and occupy the personality of the victim.

As flies to wanton boys are we to th' gods,

They kill us for their sport. ${ }^{1}$

John McCain's bones may have been broken, but his spirit never was. ${ }^{2}$

\footnotetext{
* University Professor and Professor of Law and Philosophy, Georgetown University Law Center.

** Senior Research Fellow, Centre for International Studies, Oxford, and Senior Research Fellow Emeritus, Merton College, Oxford. The authors wish to thank Michael Froomkin, Stephen Nathanson, Saul Smilansky, and participants in workshops at Pace University, University of Miami, University of Oxford, and University of Sao Paulo for comments on earlier drafts.

${ }^{1}$ William ShaKespeare, The Complete Plays and Poems of William ShaKesPeare, ed. W.A. Neilson \& C.J. Hill (Cambridge: Houghton Mifflin, 1942), 1166. [King Lear, act 4, scene 1, lines 32-37]

${ }^{2}$ [U.S. Senator] Fred Thompson, Speech at Republican National Convention, Sept. 3, 2008.
} 
Torture can be psychological as well as physical. Prolonged isolation, sensory deprivation, humiliation and sexual degradation, close confinement in coffin-like boxes, and threats to yourself or those you love, all produce horrific mental suffering. The forms it takes are hardly mysterious, and we can describe them in everyday language as well as psychiatric categories: despair, loneliness, disorientation, terror, depression, confusion, claustrophobia, anxiety, loss of personality. Mental suffering may take the form of clinically recognized psychiatric conditions like PTSD, but it need not.

Both U.S. and international law recognize that torture can be psychological as well as physical. The UN Convention Against Torture and Other Cruel, Inhuman or Degrading Treatment or Punishment (CAT, for short) defines torture as "severe pain or suffering, whether mental or physical," and the U.S. torture statute likewise recognizes that "severe physical or mental pain or suffering," intentionally inflicted by government agents, constitutes torture, a crime that carries sentences up to 20 years to life. ${ }^{3}$ The similarity is no coincidence: the statute represents Congress's implementation in 1994 of CAT, as required by Article 4 of the Convention. The convention and the U.S. torture statute also specify mens rea and circumstance in their definitions of the crime of torture, but the "severe physical or mental pain or suffering" formula is the definitional core of what it is that torturers inflict on their victims.

Unfortunately, the law Congress enacted narrows and distorts the meaning of CAT's core formula in the case of mental torture. It includes a cramped, convoluted, and arbitrary definition of mental pain or suffering, so narrow that very few techniques of mental torment qualify as torture under the law. In brief—we will discuss the details later- the torture statute restricts

\footnotetext{
${ }^{3}$ UN Convention Against Torture and Other Cruel, Inhuman or Degrading Treatment or Punishment, UN Gen. Ass. Res. 39/46 (1984)[hereinafter: CAT], Article 1; 18 U.S.C . $\$ 2340(1)$. The penalties are defined in 18 U.S.C. §2340A(a).
} 
mental torture to just four techniques and labels the victim's experience "severe mental pain or suffering" only if it is a prolonged harm the torturer specifically intends to cause. ${ }^{4}$ These restrictions are wrongheaded, because they have nothing to do with the basic definition of torture as severe pain or suffering. They also make it nearly impossible to prosecute psychological torture, including the most egregious techniques used in the CIA's now-shuttered secret prisons and in Guantánamo.

By itself, the definitional confusion might signify nothing more than a peculiarity in the U.S. criminal statutes against torture. Congress may have tailored its definition around the need to specify elements easily proven in a court of law. However, the confusion runs broader than the criminal law. The legal definition derives from an "understanding" of mental pain and suffering the U.S. Senate attached to CAT at its ratification—an "understanding" that we shall argue misunderstands mental torture and reneges on the U.S. obligation under CAT to criminalize "all acts of torture." Our main aim in this paper is to expose the fallacies that make U.S. torture law nearly useless for defining and repressing psychological torture. ${ }^{6}$ We identify three basic fallacies: the materialist bias that somehow the psychological is less real than the physical and should be viewed with suspicion; the substitution trick according to which mental pain and suffering get defined through their causes and aftermath and not the experience itself; and the forensic fallacy, which confuses the due process requirement of narrowness and precision in criminal statutes with defining features of the crime's gravamen itself. In addition, the specific intent requirement attached to the crime of mental torture is worded in a way that exonerates all but the most sadistic torturers.

\footnotetext{
${ }^{4} 18$ U.S.C. $\$ 2340(1)$ and (2).

${ }^{5}$ CAT, Article 4(1)("Every State Party shall ensure that all acts of torture are offences under its criminal law."

${ }^{6}$ We use "psychological torture" and "mental torture" interchangeably in this article.
} 
None of these are innocent fallacies. A careful examination of the legislative record reveals no attempt to defend the definition of mental torture on the merits, or even to explain its distinctive features. Instead, as we show, one finds repeated concerns that unless the definition of mental torture is written narrowly, U.S. law enforcement officials might face accusations of torture. ${ }^{7}$ In other words, the definition of mental torture was narrowed for reasons of liability screening, not reasons of definitional accuracy.

During the administration of President George W. Bush, officials approved harsh interrogation tactics after their lawyers assured them that the tactics did not meet the legal definition of the crime of torture. By now it is well understood that government lawyers used questionable interpretive methods to reach their conclusion that stress positions, wall-slamming, dousing with cold water, and waterboarding are not severe enough to constitute physical torture. The Justice Department itself has officially condemned these interpretations as "bad judgment," after initially finding them grounds for recommending professional discipline. ${ }^{8}$ Regrettably, the law defining mental pain and suffering is itself so flawed that the torture lawyers had little need for frivolous interpretations to absolve interrogators inflicting systematic humiliation, prolonged isolation, threats to "disappear" a detainee, sleep deprivation, and other techniques of

\footnotetext{
${ }^{7}$ See infra, notes 39-40, 50, 72, 81-84, and accompanying text.

${ }^{8}$ For detailed analysis of the memos, see David Luban, The Torture Lawyers of Washington, in LEGAL ETHICS AND Human DigniTy (2007); Testimony of David Luban, Senate Judiciary Committee, Subcommittee on Administrative Oversight and the Courts, Hearing: "What Went Wrong: Torture and the Office of Legal Counsel in the Bush Administration," May 13, 2009 (on file with authors). Focusing on one of the torture memos, the Office of Professional Responsibility (OPR)—the U.S. Department of Justice's internal ethics watchdog—demonstrated in detail how the government lawyers distorted the law. See OPR, Investigation into the Office of Legal Counsel's Memoranda Concerning Issues Relating to the Central Intelligence Agency's Use of "Enhanced Interrogation Techniques" on Suspected Terrorists, draft report Dec. 22, 2008; final report July 29, 2009. Not everyone agrees: a senior Justice Department official, David Margolis, reviewed the OPR reports critically and downgraded their findings that the government lawyers had committed professional misconduct to a finding of bad judgment. The OPR reports, Margolis's critique, and other relevant documents may be found on the House Judiciary Committee's website, http://judiciary.house.gov/issues/issues_OPRReport.html (viewed Nov. 29, 2010). One of us has rebutted Margolis's analysis: David Luban, David Margolis Is Wrong, SLATE.COM, Feb. 22, 2010, available at http://www.slate.com/id/2245531/.
} 
psychological torture. The law's definition of mental torture is so narrow that the lawyers had to add only the slightest dash of interpretive exaggeration to reach their conclusions. ${ }^{9}$

Thus the problem is deeper than the legal maneuvers of a single U.S. Administration, and its origins go back decades. The effort to minimize mental torture has continued for twenty years since the time of President Reagan's submission of CAT for Senate ratification in 1988 and its actual ratification six years later in the first Clinton Administration. ${ }^{10}$ Congress implemented CAT through the Torture Act of 1994 and additionally prohibited torture through the War Crimes Act of 1996, both signed into law by President Bill Clinton. ${ }^{11}$ Both statutes incorporated the same flawed definition of mental torture and the same fallacies. The Military Commissions Act (MCA) of 2006 perpetuated the misunderstandings and even piled on additional confusion in its definitions, and the Military Commissions Act of 2009 left those misunderstandings intact. ${ }^{12}$ Narrowly defining mental torture, then, did not begin in the George W. Bush Administration -- it has been the consistent U.S. government line for two decades through five presidencies including the ten years of two Democratic presidents, Bill Clinton and Barack Obama. This thinking is, nevertheless, a distortion of the general understanding of torture as the intentional infliction of severe pain or suffering. As we noted above, the record reveals a persistent anxiety among U.S. officials that law enforcement abuses, punishment practices, and--since 9/11--interrogation methods might be labeled torture. Even though the Torture Act is explicitly limited to conduct that takes place outside the United States, the drafters seem to have feared the public relations

\footnotetext{
${ }^{9}$ See text accompanying notes 54-55, infra, where we analyze this interpretive exaggeration.

${ }^{10}$ Alfred W. MCCoy, A Question of TORTURE: CIA InTERrogation, From the COLd WAR to the WAR ON TERROR 100-02 (2006).

1118 U.S.C. $\S \S 2340-2340$ A, 18 U.S.C. $\$ 2441$.

1218 U.S.C. $\$ 2441(d)(2)(E)($ defining "serious mental pain or suffering," a lesser category than "severe mental pain or suffering").
} 
consequences of a legal standard under which the United States might come to be seen as a nation that practices torture.

We begin by discussing right and wrong ways to think about mental pain and suffering and how the law should treat them. Next we briefly catalogue examples and types of recent U.S. mental torture (section I). We then sketch the features of the U.S. legal treatment of torture during the last quarter of a century and identify the fallacies that underlie it (sections II-IV). We finally indicate what is distinctively objectionable about the kind of mental torture that U.S. laws obscure from view (section V). This, we argue, is the special evil of breaking the resistance of a prisoner by breaking his mind. ${ }^{13}$

\section{Mental Pain and Suffering}

\footnotetext{
${ }^{13}$ The mercilessness for which we will in the end condemn psychological torture is suggested in Henry Shue, Torture, 7 PHIL. \& PUB. AFF., 124 (1978). Most subsequent philosophical discussions of torture, which were relatively rare until the last few years but have now, depressingly, expanded to a large library, focus on tickingbomb scenarios for torture without much attention to the nature of the torture itself or to which of its features provide the grounds for its wrongfulness. An important article on such scenarios is Vittorio Bufacchi and Jean Maria Arrigo, Torture, Terrorism and the State: A Refutation of the Ticking-Bomb Argument, 23 J. APPLIED PHIL. 355 (2006). See also Association for the Prevention of Torture, Defusing the Ticking Bomb Scenario: Why we must say No to torture, always (2007), available at http://www.apt.ch/index.php?option=com_docman\&task=doc_details\&gid=297\&Itemid=250\&lang=en. Recent book-length studies are BOB BRECHER, TORTURE AND THE TICKING BOMB (2007); and YuvAL GinBAR, WHY NOT TORTURE TERrorists? MORAL, PRACTICAL, AND LEGAL ASPECTS OF THE ‘TICKING BOMB’ JUSTIFICATION FOR TORTURE (2008). Both of us have argued against the distortions that the "ticking bomb scenario" introduces into discussions of torture. See David Luban, Liberalism, Torture, and the Ticking Bomb, in THE TORTURE DEBATE IN AMERICA 35 (Karen Greenberg, ed., 2005); Luban, Unthinking the Ticking Bomb, in GlOBAL BASIC RIGHTS 181 (Charles R. Beitz \& Robert E. Goodin eds., 2009); Shue, Torture in Dreamland: Disposing of the Ticking Bomb, 37 CASE WESTERN RESERVE J. INT'L L. 231 (2006). Notable exceptions to the general tendency to neglect to probe the nature of the torture itself have been David Sussman, What's Wrong with Torture? 33 PHIL. \& PUB. AFF. 1 (2005); Jessica Wolfendale, The Myth of 'Torture Lite', 23 ETHICS \& INT. AFF. 47 (2009); and David Sussman, 'Torture Lite': A Response, 23 ETHICS \& INT. AFF. 63 (2009). See also Luban, Human Dignity, Humiliation, and Torture, 19 KENNEDY INST. J. ETHICS 211 (2009). A major historical survey of the varieties of torture is DARIUS REJALI, TORTURE AND DEMOCRACY (2007); and other extensive recent philosophical discussions include RICHARD Matthews, The Absolute Violation: Why Torture Must Be Prohibited (2008); JessicA WolfEndale, TORTURE AND THE MILITARY PROFESSION (2007); and CHARLES FrIED \& GREGORY FrIED, BECAUSE IT Is WRONG: TORTURE, PRIVACY AND PRESIDENTIAL POWER IN THE AGE OF TERROR (2010). Useful accounts of current torture practices include MATTHEW AlEXANDER WITH JOHN R. BRUNING, HOW TO BREAK A TERRORIST: THE U.S. InTERrogators Who Used Brains, Not Brutality, To TAKe Down THE DEADLIEST Man IN IRAQ (2008); Chris MACKey AND Greg Miller, The InTERrogators: Inside the SECRET WAR AgAinst Al QAeda (2004); and Mark Danner, US Torture: Voices from the Black Sites, NY REV. BOOKS, Apr. 9, 2009, available at http://www.nybooks.com/articles/archives/2009/apr/09/us-torture-voices-from-the-black-sites/. (leaking and analyzing confidential ICRC report on high value detainees). We are not aware of a conceptual analysis of U.S. legal definitions of torture.
} 
Leaving to one side the elements of mens rea and circumstance in CAT's definition of torture, we observe that the drafters constructed it around two pairs of distinctions: pain and suffering, mental and physical. The definition is neither novel nor eccentric: it appears to be modeled on the 1971 Oxford English Dictionary definition of 'torture' as "severe or excruciating pain or suffering (of body or mind)...."14 A third distinction is implicit in the structure and text of the treaty: pain or suffering that take the form of torture and under Article 4 must be criminalized, and cruel, inhuman, or degrading treatment other than torture, which under Article 16 need not be criminalized but must be prevented. We set this third distinction aside and offer a few observations about the first two.

The most obvious point is that "severe pain or suffering" refers to what the torture victim experiences. It does not refer to the technique that caused the experience, or to its lingering aftereffects. The pain or suffering, according to the law, may be mental or physical, and the conceptual question is how to distinguish these.

In both CAT and the U.S. statutes, the phrase is "pain or suffering," not "pain and suffering." Either pain or suffering can count as torture. This turned out to be an important point in the Bush Administration's torture memos, two of which interpreted "pain or suffering" as a unitary concept, and therefore concluded that if a technique like waterboarding does not produce physical pain, it doesn't produce physical suffering either. ${ }^{15}$ But of course forms of physical suffering exist that aren't pain: freezing cold, unbearable heat, itching, nausea, paralysis, acheall-over, unable to breathe-all are suffering, none are pain. Unable to breathe gets to the heart

\footnotetext{
14 The COMPACT OXFORD ENGLISH DiCTIONARY 3357 (1971).

${ }^{15}$ See Memorandum to Alberto R. Gonzales from Jay S. Bybee, Standards of Conduct for Interrogation under 18 U.S.C. $\$ \$ 2340-2340 A$ (Aug. 1, 2002), reprinted in DAVID Cole, THE TORTURE MEMOS: RATIONALIZING THE UnthinKABLE 41, 48 n. 3 (2009) [hereinafter: Bybee/Yoo Torture Memo]; Memorandum to John Rizzo from Jay S. Bybee, Interrogation of Al Qaeda Operative (Aug. 1, 2002), at 11, in CoLE, at 106, 118 [hereinafter: Bybee/Yoo Techniques Memo].
} 
of waterboarding, which is controlled suffocation. After the Justice Department withdrew the Bybee/Yoo memoranda, Acting Assistant Attorney General Daniel Levin wrote a substitute memo that conceded "that under some circumstances 'severe physical suffering' may constitute torture even if it does not involve 'severe physical pain.",16

Even though physical pain and suffering are distinguishable, it is less clear that mental pain is different from mental suffering. The U.S. statutory definition of severe mental pain or suffering treats them together; ${ }^{17}$ and, although we reject that definition in most respects, we have no strong linguistic or moral intuitions that mental pain and mental suffering represent categorically different phenomena. Perhaps a terrible memory that suddenly comes back to the surface with agonizing force would better be described as "mental pain" than "mental suffering"; the phrase "painful memories" belongs to ordinary English with no corresponding phrase for the word "suffering." But we don't perceive a sharp, stable distinction between mental pain and mental suffering; and our discussion will not assume a distinction between the two.

What then is "mental pain or suffering"? How does it differ from physical pain or suffering? Before addressing these questions, we want to ward off several tempting errors and red herrings.

First, we think it is a mistake to get too theoretical or too deep in differentiating the mental from the physical. You don't need a solution to the mind-body problem to draw CAT's distinction between mental and physical suffering, and it may be that a philosophically adequate solution to the mind-body problem would actually muddy the waters. It might, for example, discredit CAT's legal distinction by showing that it presupposes an untenable "ghost in the

\footnotetext{
${ }^{16}$ Memorandum for James R. Comey from Daniel Levin, Legal Standards Applicable Under 18 U.S.C. $\$ 2340-$ $2340 A$ (Dec. 30, 2004)[hereinafter: Levin Memo], reprinted in COLE, supra note 15, at 128, 141.

${ }^{17} 18$ U.S.C. $\$ 2340(2)$.
} 
machine" picture of mind's relation to body. ${ }^{18}$ Or it might show that deep down it's all ghost or all machine, so that the legal distinction falsifies reality.

Even careful writers are vulnerable to theory-driven over-claiming that in our view is unnecessary and potentially confusing. Thus, one writer whose article is in other respects a source of insight denounces the distinction between physical and psychological torment as "untenable" because "[a]ll pain is at root psychological—an affliction of feeling whose defining characteristic is that it hurts." 19

Of course one could with equal justification say that all pain is at root physical, since it involves neuron and brain activity-and other writers say precisely that. ${ }^{20}$ But we doubt that asking what pain is "at root" will shed light on the law, which operates in the theoretical shallows using ordinary language categories (what theorists call "folk psychology"). In ordinary language, a searing pain in the shoulder is physical, not mental, and it is not "at root" psychological. Or rather, calling it psychological refers in ordinary speech to etiology, not ontology. It means that the shoulder pain is caused by emotional or mental disturbance, rather than, say, by a bone chip pressing against a nerve. Pain can be psychosomatic without being any the less physical: it's still a sore shoulder, not an achy breaky heart. Psychosomatic physical pain is obviously not what CAT means by "severe mental pain or suffering."

\footnotetext{
${ }^{18}$ The phrase originates in Gilbert Ryle's classic of philosophical behaviorism, THE CONCEPT OF MIND 15-16 (1949).

19 Jamie Mayerfeld, Playing By Our Own Rules: How the US Marginalization of International Human Rights Law Led to Torture, 20 HARV. Human Rights J. 89, 130 (2007).

20 "Thus, to think that psychological torture is not an assault on the body is a conceptual error from the outset. [W] hat all torture has in common, regardless of physical or mental appearances, is its assault on the brain. ... Extreme fear and despair ... are emotional states that are anchored in brain states." Uwe Jacobs, Documenting the Neurobiology of Psychological Torture: Conceptual and Neuropsychological Observations, in THE TRAUMA OF PSYCHOLOGICAL TORTURE 163, 164-65 (Almerindo E. Ojeda ed., 2008). "Torture is speciously categorized as physical ... or as psychological. This is a distinction without a difference. Coercion of any type ... can and often does impact on brain, spinal cord, and organ integrity and therefore has medical consequences." Rona M. Fields, The Neurobiological Consequences of Psychological Torture, in THE TRAUMA OF PSYCHOLOGICAL TORTURE, at 139.
} 
In our ordinary language view, mental pain and suffering simply means the kind of pain or suffering we describe using psychological terms like "anxiety," "terror," "humiliation," "despondency," "broken-heartedness," "grief," etc. (We wish we had a handy categorical way of describing these, but we do not). What makes them mental is that the terms name emotional states; what makes them pain and suffering is that they feel bad; and what makes them severe is how bad they feel. There may be vagueness here, but there is no mystery.

Physical pain and suffering have their own vocabularies. With physical pain we talk about bodily regions: it hurts here, not there; it moves around; it's in my shoulder, but I can't pinpoint exactly where. We also talk about physical pain's character: sharp, dull, burning, stabbing, mild, unbearable. Physical suffering other than pain gets described by terms like "stifling hot," "freezing cold," "itching," or “nauseous.” Approaching CAT's mental/physical distinction through the ordinary language we use to describe pain and suffering avoids the need for theory-laden descriptions that require some account of the mind-body relationship.

Second, we acknowledge that mental pain and suffering can cause physical effects and, vice-versa, that physical pain and suffering can cause mental effects-including mental pain and suffering. Loneliness, as induced for example by solitary confinement, floods the body with stress hormones, raises blood pressure, accelerates aging, damages cognition, and weakens the immune system. ${ }^{21}$ Thus the mental torture of prolonged isolation or long-term solitary confinement need not cause purely mental damage. Conversely, physical pain and suffering can cause depression, PTSD, despair, fear, feelings of loneliness and isolation, and inability to concentrate. That makes physical torture a sometime source of mental torture as well.

\footnotetext{
${ }^{21}$ JOHN T. CACCIOPO \& WILLIAM PATRICK, LONELINESS: HUMAN NATURE AND THE NEED FOR SOCIAL CONNECTION (2009); see also Stuart Grassian, Neuropsychiatric Effects of Solitary Confinement, in THE TRAUMA OF PSYCHOLOGICAL TORTURE, supra note 20, at 113-26; Fields, supra note 20.
} 
In our view, though, both these observations are completely consistent with folk psychology's distinction between mental and physical suffering. That A causes B, or even that A invariably causes B, does not imply that A and B are indistinguishable. Of course, if A and B always co-occur, we may decide to regard them as simply two aspects or pieces of a single thing, call it C. We may so decide—but intellectual rigor doesn't compel us to do so, and even if we do switch from "A-B" talk to "C" talk for scientific purposes, nothing prevents us from retaining the distinction between A and B for whatever purposes it remains useful. That is how we should think of the distinction between mental and physical torture: a useful one for the pre-theoretical purposes of CAT and for moral discussions of torture, regardless of whether medical investigation eventually proves that the two forms of suffering are, in fact, always yoked together.

Third, some forms of suffering may be both physical and psychological, or have aspects of both. Waterboarding, which combines suffocation with panic, is an example. Bombarding prisoners with earsplitting, culturally repugnant rock music for hours on end is another. Forcing prisoners to piss and shit on themselves is a third; the suffering of lying in your own excrement is physical as well as mental. And prolonged sleep deprivation is a fourth: your body hurts and feels hypersensitive, and your mind functions abnormally, your emotions run riot, and your will may collapse. All these techniques have been used by U.S. interrogators, and sleep deprivation was a favorite technique: Guantánamo inmate Mohammed al Qahtani was kept awake twenty hours a day for 48 days out of 54 , and the torture memos approved sleep deprivation of up to 180 hours (seven and a half consecutive days and nights)—noting that "to date, more than a dozen detainees have been subjected to sleep deprivation of more than 48 hours, and three detainees have been subjected to sleep deprivation of more than 96 hours; the longest period of time for 
which any detainee has been deprived of sleep by the CIA is 180 hours." ${ }^{22}$ Detainees were kept awake naked, diapered, and hanging in chains or, alternatively, shackled to a stool "too small to permit the subject to balance himself sufficiently to be able to go to sleep." ${ }^{23}$ They were kept under non-stop observation, which the torture memos regarded as a salutary precaution guaranteeing that the suffering would be stopped before it crossed the line into torture, but which common sense would count as an additional humiliation—and thus a further candidate for mental torture rather than a precaution against it.

Despite uncertainties in all these examples about whether to label the suffering mental, physical, or both, the distinction between mental and physical suffering remains intact. Borderline cases between concepts do not invalidate the concepts.

Our basic point in this section is simple: folk psychology and ordinary speech recognize psychological states that count as severe pain or suffering for the obvious reason that they feel so bad. We have a rich vocabulary for them: words like "grief," "loneliness," "heartbreak," "terror," and "despair" only begin to scratch a surface that poets and songwriters explore in its depths.

What makes these states count as pain or suffering is the way they feel-their phenomenology. It is not their causes and not their effects that make them pain or suffering. At bottom, our conceptual critique of U.S. law is that its drafters mistakenly defined "severe mental pain or

\footnotetext{
${ }^{22}$ Memorandum for John A. Rizzo from Steven G. Bradbury, Re: Application of 18 U.S.C. $\$ \$ 2340-2340$ A to Certain Techniques That May Be Used in the Interrogation of a High Value al Qaeda Detainee (May 10, 2005), in COLE, supra note 15, at 152, 167-68 [hereinafter: Bradbury Techniques Memo]. On the sleep deprivation of Qahtani, see Lt Gen Randall M. Schmidt, Army Regulation 15-6: Final Report (executive summary)—Investigation into FBI Allegations of Detainee Abuse at Guantanamo Bay, Cuba Detention Facility (April 1, 2005, amended June 9, 2005)[hereinafter: Schmidt Report], available at http://www.defense.gov/news/Jul2005/d20050714report.pdf (accessed Dec. 18, 2010), at 17. Even in the ancient world, sleep deprivation was understood to be torture. Cicero characterizes the execution of Regulus by the Carthaginians through "enforced wakefulness" (vigilando) as "exquisite torture" (exquisita supplicia). MARCUs TUllius CICERO, DE OFFICIIS 377-78 (Loeb Classical Library, Walter Miller trans. 1913), III.xxvii.100. The Supreme Court described sleep deprivation as torture in Ashcraft v. Tennessee, 322 U.S. 143, 150 n. 6, 155 (1944); the Court likened Ashcraft's 36 hour long interrogation to "the inquisition of the Middle Ages," id. at 152 n. 8.

${ }^{23}$ Id. at 166.
} 
suffering" through a small set of causes and effects, leaving nothing but a blank where the experience itself belongs; and our moral critique is that substituting these causes and effects lets torturers off the hook.

Of course, knowing causes or effects can be important evidence of the type and severity of mental pain or suffering. Consider the horrible example of a man or woman who watches a beloved child die in an accident that the parent's carelessness caused. No sane person can doubt that the parent's mental pain and suffering is as terrible as pain and suffering can be. Without knowing the cause, outsiders might not appreciate the depth of the suffering, or understand its character - that it is composed of grief, guilt, self-hatred, and despair. Importantly, you don't need to experience it yourself to know these things. In fact, a poet might use the example figuratively to describe suffering caused by something entirely different. That possibility might tempt us to confuse the cause with the suffering, because here to name the cause is to describe the suffering. But let's be clear: the mental pain and suffering is the waves of anguish rolling over the parent, not the cause of the anguish. Similar confusions exist in describing physical pain: the word "burning" can be used either to describe a sensation or to name its cause; and of course a burning sensation need not be caused by actual burning. Similarly when we turn from causes to effects. The flashbacks, nightmares, and cognitive deficits experienced by torture survivors with PTSD provide evidence that their pain and suffering must have been severe when they were being tortured; and of course these symptoms are themselves forms of mental pain or suffering. However, the PTSD symptoms are not themselves the mental suffering experienced during the trauma.

II. Mental Torture in Practice: A Brief Catalogue 
Before proceeding to our discussion of the law, it will help to put on the table the forms that mental torture actually takes. The legal standard of infliction of severe mental pain or suffering provides the general rubric; but what, in historical experience, have been the methods of mental torture? In particular, what has been the U.S. experience? In the brief section that follows, we focus on mental torture as used in the U.S. conflict with Al Qaeda, not because it is the only, or worst, national practice of mental torture in the world, but because it has been the most prominent topic of public debate in recent years - and, of course, because our topic is U.S. law.

The story of America's involvement with mental torture has been told before, and we will not retell it in detail here. ${ }^{24}$ In brief, the CIA and military authorities began research into mental torture in the 1950 s to understand the baffling phenomenon of patently false confessions that Communist regimes were able to elicit from their victims, including Soviet political prisoners and, during the Korean War, captured U.S. service members. How did they do it? How do you "brainwash" someone? The only way to study the KGB techniques was to replicate them, and a surprising amount of research by eminent civilian psychologists was funded by the government for just these purposes. It discovered that seemingly minor manipulations of a prisoner's environment - disruptions of space and time by capriciously varying schedules and environment, isolation, sensory and sleep deprivation, irregular sleep, and extremes of hot and cold—could cause major degradations of the victim's personality. Piling them one on top of the other is even

\footnotetext{
${ }^{24}$ Readers may consult Alfred McCoy's history of the CIA's involvement, in A QUESTION OF TORTURE, supra note 10, Darius Rejali's large-scale study TORTURE AND DEMOCRACY, supra note 13, and JANE MAYER, THE DARK SIDE: THE INSIDE STORY OF HOW THE WAR ON TERROR TURNED INTO A WAR ON AMERICAN IDEALS (2008). The brief account that follows comes largely from these sources.
} 
more devastating. Much of this lore was compiled in manuals that later became public, such as the CIA's "Kubark" manual. ${ }^{25}$

The major practical payoff of these experiments (occasionally conducted on unwilling subjects) was training methods for special forces in how to resist mental torture. In the SERE training - 'SERE' stands for Survival, Evasion, Resistance, Escape— 'R' for “resistance” means precisely training in how to resist a captor's efforts to break you down.

In the wake of 9/11, a pair of psychologists, private consultants to the U.S. government, persuaded officials that the most effective way to interrogate detainees would be through techniques used in SERE training. ${ }^{26}$ In other words, SERE was reverse-engineered, so protocols designed to teach SEALs how to resist torture were mined for the techniques that the SEALs were being trained to resist. Behavioral science consultation teams, or "biscuits" (BSCTs) were attached to interrogation teams in Guantánamo and elsewhere. ${ }^{27}$

One result was the repertoire of techniques detailed in the torture memos, used on highvalue detainees in the CIA's secret prisons. The Bybee-Yoo memo details ten techniques, while the Bradbury memo expands the list to thirteen, used in combination. ${ }^{28}$ Some of these are physical (the Belly Slap, the Facial Slap, Wall Slamming, dousing with cold water, waterboarding), although the goal of piling small physical insults atop each other is

\footnotetext{
${ }^{25}$ McCoY, supra note 10, at 50-53.

${ }^{26}$ The adventures of Mitchell and Jessen were first exposed by two major works of investigative journalism. Jane Mayer, The Experiment, The New Yorker, July 11, 2005, available at http://www.newyorker.com/archive/2005/07/11/050711fa_fact4 (accessed Feb. 14, 2011), and Katherine Eban, Rorschach and Awe, Vanity Fair, July 17, 2007, available at http://www.vanityfair.com/politics/features/2007/07/torture200707 (accessed Feb. 14, 2011).

${ }^{27}$ For a detailed description and time line of these events, see the Senate Armed Services Committee's report Inquiry Into the Treatment of Detainees in U.S. Custody, $110^{\text {th }}$ Cong. $2^{\text {nd }}$ session, Nov. 20, 2008.

One of the authors (Luban) interviewed an interrogator who had worked in Iraq and asked him about the role of the BSCTs. The interrogator responded that they played a minor role, but that a BSCT had instructed him in how to induce Stockholm Syndrome in a detainee. He said it is very easy to do, but remarked that he personally felt it was immoral, and reminded him of Arthur Koestler's Darkness at Noon and Dostoevsky's Grand Inquisitor.

${ }_{28}$ The Bybee-Yoo list is in their techniques memo, reprinted in COLE, supra note 15, at 107; the Bradbury list is in his techniques memo, reprinted in COLE, supra note 15, at 159-71.
} 
psychological suffering. Others are purely psychological: nudity, sleep deprivation, and close confinement in small spaces. Consider this passage from the Bybee-Yoo Techniques Memo:

You would like to place Zubaydah in a cramped confinement box with an insect. You have informed us that he appears to have a fear of insects. In particular, you would like to tell Zubaydah that you intend to place a stinging insect in the box with him. You would, however, place a harmless insect in the box. ${ }^{29}$

The insect technique is an attempt to exploit a phobia, and is therefore deliberately psychological; unlike cramped confinement sans insect it was never employed. Obviously, cramped confinement is itself purely psychological, although in his effort to explain why cramped confinement is not mental torture, the CIA counsel John Rizzo "informed us that your purpose in using these boxes is not to interfere with his senses or his personality, but to cause him physical discomfort.... ${ }^{30}$ The answer is incredible-lying in a confined space is no more physically uncomfortable than lying in an open space. Evidently all three lawyers were nervous that the technique might be mental torture. Perhaps they remembered that in Orwell's 1984 it was the exploitation of Winston Smith's rat phobia, not physical torture, that finally broke him and made him betray his beliefs and his lover.

At Guantánamo, interrogators subjected detainees to a "frequent flyer" sleep interruption program in which "[d]etainees were moved dozens of times in just days and sometimes more than a hundred times over a two-week period."31 The interrogation of Mohammed al-Qahtani included not only the intensive sleep deprivation described earlier, but also a barrage of sexual and other humiliations described in the Schmidt Report:

\footnotetext{
29 Bybee-Yoo Techniques Memo, reprinted in COLE, supra note 15, at 109.

${ }^{30}$ Id. at 121.

31 Josh White, Tactic Used After It Was Banned: Detainees at Guantanamo Were Moved Often, Documents Say, Wash. Post, Aug. 7, 2008.
} 
Finding \#16b: On $06 \mathrm{Dec}$ 02, the subject of the first Special Interrogation Plan was forced to wear a woman's bra and had a thong placed on his head during the course of the interrogation.

Finding \#16c: On 17 Dec 02, the subject of the first Special Interrogation Plan was told that his mother and sister were whores.

Finding \#16d: On 17 Dec 02, the subject of the first Special Interrogation Plan was told that he was a homosexual, had homosexual tendencies, and that other detainees had found out about these tendencies.

Finding \#16e: On 20 Dec 02, an interrogator tied a leash to the subject of the first Special Interrogation Plan's chains, led him around the room, and forced him to perform a series of dog tricks.

Finding \#16f: On 20 Dec 02, an interrogator forced the subject of the first Special Interrogation Plan to dance with a male interrogator.

Finding \#16h: On one occasion in Dec 02, the subject of the First Special Interrogation Plan was forced to stand naked for five minutes with females present. This incident occurred in the course of a strip search. ${ }^{32}$

Qahtani was also threatened with a military working dog. ${ }^{33}$ Four of these techniquesthreatening with a dog, women's underwear over the head, nudity in the presence of female soldiers, and leading the victim around on a leash—soon migrated to Abu Ghraib, where they appeared in iconic and devastating photographs. Eventually, Susan Crawford, the convening authority (i.e., head) of the Military Commissions, refused to prosecute Qahtani because "[h]is

\footnotetext{
${ }^{32}$ Schmidt Report, supra note 22, at 19. Schmidt concluded that taken together with 20-hour-a-day interrogations, these techniques were "degrading and abusive," although "this treatment did not rise to the level of prohibited inhumane treatment." Id. at 20.

33 Id. at 14.
} 
treatment met the legal definition of torture. And that's why I did not refer the case." ${ }^{34}$ This was the first (and to our knowledge only) occasion on which a Bush Administration official publicly used the word "torture" to describe the treatment of a detainee.

Prolonged isolation is one of the worst techniques; apparently companionship is a basic human need, and complete solitude one of the most painful human experiences. ${ }^{35}$ According to the U.S. government, isolation became a centrally important technique used against the "dirty bomb" conspirator Jose Padilla. ${ }^{36}$ Padilla was held in isolation from June 2002 until March 2004, when (with Padilla's Supreme Court case looming) authorities finally permitted a visit from his attorney.

It would be tedious to continue the catalogue of techniques. Whether or not you agree that these techniques are severe enough to qualify as torture, our point in describing them is to make it clear that the United States is no stranger to the deliberate infliction of mental suffering.

We will follow a characterization by Almerindo E. Ojeda who (reviewing evidence from several countries) finds thirteen forms that mental torture has characteristically taken:

A1. Isolation: solitary confinement (no human contact whatsoever) or semi-solitary confinement (contact only with interrogators, guards, and other personnel ancillary to the detention).

A2. Psychological Debilitation: the effect of deprivation of food, water, clothes, or sleep, the disruption of sleep cycles, prolonged standing, crouching, or kneeling, forced physical exertion, exposure to temperatures leading to stifling or hypothermia.

\footnotetext{
${ }^{34}$ Bob Woodward, Detainee Tortured, Says U.S. Official, Wash. Post, Jan. 14, 2009.

${ }^{35}$ See the sources cited in note 21, supra, as well as Atul Gawande, Hellhole, The New Yorker, Mar. 30, 2009 (discussing long-term solitary confinement).

${ }^{36}$ See the so-called "Jacoby Declaration" introduced as evidence to oppose granting Padilla access to counsel. Declaration of Vice-Admiral Lowell E. Jacoby, Director of the Defense Intelligence Agency, Jan. 9, 2003, available at http://www.pegc.us/archive/Padilla_vs_Rumsfeld/Jacoby_declaration_20030109.pdf at 5 (describing need to maintain relationship of "dependency and trust" between Padilla and interrogators that contact with lawyers would disrupt).
} 
A3. Spatial Disorientation: confinement in small places; small, darkened or otherwise nonfunctional windows.

A4. Temporal Disorientation: denial of natural light; nighttime recreation time; erratic scheduling of meals, showers, or otherwise regular activities.

A5. Sensory Disorientation: use of magic rooms, i.e., holding facilities or interrogation chambers that induce misperceptions of sensory failure, narcosis, or hypnosis.

A6. Sensory Deprivation: use of hooding, blindfolding, opaque goggles, darkness, sound proofing/canceling headsets, nasal masks (possibly deodorized), gloves, arm covers, sensory deprivation tanks or vaults.

A7. Sensory assault (Overstimulation): use of bright or stroboscopic lights; loud noise (or music); shouting or using public address equipment at close range.

A8. Induced desperation: arbitrary arrest; indefinite detention; random punishment or reward; forced feeding; implanting sense of guilt, abandonment, or "learned helplessness."

A9. Threats: to self or to others, threats of death, physical torture, or rendition; mock executions; forced witnessing of torture (visually or aurally).

A10. Feral treatment: berating victim to the subhuman level of wild animals; forced nakedness; denial of personal hygiene; overcrowding; forced interaction with pests; contact with blood or excreta; bestiality; incest.

A11. Sexual humiliation: forcing the victim to witness or carry out masturbation, copulation, or other forms of sexual behavior.

A12. Desecration: forcing victims to witness or engage in the violation of religious practices (irreverence, blasphemy, profanity, defilement, sacrilege, incest, Satanism). 
A13. Pharmacological Manipulation: nontherapeutic use of drugs or placebos. ${ }^{37}$

Ojeda's catalogue may not be exhaustive, because human beings have never lacked inventiveness in devising new forms of cruelty. But it gives some sense of what we are talking about.

\section{Obscuring Mental Pain and Suffering}

A. The Senate RUDs

CAT was adopted internationally in 1984, ten years before U.S. ratification. From the beginning, the U.S. Government has made persistent efforts to deny or dilute the half of the definition of torture that covers mental pain and suffering.

The campaign to erase or minimize psychological torture began with the understandings submitted to the U.S. Senate in 1988 by the Reagan White House and State Department when CAT was submitted for ratification. ${ }^{38}$ The report submitted to the Senate Foreign Relations Committee expresses concern that someone might apply CAT's definition to U.S. law enforcement practices, and particularly to "“police brutality,' [which] while deplorable, does not amount to "torture.", ${ }^{99}$ This political worry led to several proposed understandings—-first, that CAT's exemption of pain and suffering "inherent in, or incident to, lawful sanctions" law enforcement as well as punishment, and second, that "in order to constitute torture, an act

\footnotetext{
37 Almerindo E. Ojeda, What Is Psychological Torture?, in Ojeda, supra note 20, at 2-3.

${ }^{38}$ United States, Senate, Message from the President of the United States Transmitting the Convention against Torture and Other Cruel, Inhuman or Degrading Treatment or Punishment, 100th Congress, 2d sess., S. Treaty Doc. 100-20, at 3-5. The "understanding" was part of a package of reservations, understandings, and declarations (RUDs).

${ }^{39}$ S. Treaty Doc. 100-20, supra note 38, at 3-4.

${ }^{40}$ CAT, art. 1(1).
} 
must be a deliberate and calculated act of an extremely cruel and inhuman nature, specifically intended to inflict excruciating and agonizing physical or mental pain or suffering., ${ }^{41}$

The Foreign Relations Committee rejected the proposed understandings, because they "created the impression that the United States was not serious in its commitment to end torture worldwide." ${ }^{42}$ The Committee singled out the understanding that pain and suffering must be excruciating and agonizing for "setting too high a threshold for pain for an act to constitute torture." ${ }^{43}$ In response, the George H. W. Bush Administration deleted the Reagan understanding of physical pain or suffering and proposed a substitute understanding of mental pain or suffering - the very standard that we criticize here. ${ }^{44}$ The language of that understanding has echoed through U.S. federal statutes ever since and is in force domestically today. As adopted when the Senate ratified the treaty in 1994, it reads:

II. The Senate's advice and consent is subject to the following understandings, which shall apply to the obligations of the United States under this Convention: (1) (a) That with reference to article 1, the United States understands that, in order to constitute torture, an act must be specifically intended to inflict severe physical or mental pain or suffering and that mental pain or suffering refers to prolonged mental harm caused by or resulting from (1) the intentional infliction or threatened infliction of severe physical pain or suffering; (2) the administration or application, or threatened administration or application, of mind altering substances or other procedures calculated to disrupt

\footnotetext{
${ }^{41}$ S. Treaty Doc. 100-20, supra note 38, at 4-5.

${ }^{42}$ Senate Foreign Relations Committee, Report together with Additional Views on the Convention Against Torture and Other Cruel, Inhuman, and Degrading Treatment (Aug. 30, 1990)[hereinafter: S. Exec. Rep. No. 101-30], at 4.

${ }^{43}$ Id. at 9.

${ }^{44}$ The other understanding, that "lawful sanctions" includes law enforcement as well as punishment, was retained, although modified "to make it clear that to be 'lawful,' sanctions must also meet the standards of international law." Id.
} 
profoundly the senses or the personality; (3) the threat of imminent death; or (4) the threat that another person will imminently be subjected to death, severe physical pain or suffering, or the administration or application of mind altering substances or other procedures calculated to disrupt profoundly the senses or personality. ${ }^{45}$

In brief, the U.S. understanding restricts mental pain and suffering to the prolonged harm caused by physical torture, threats of death or physical torture, mind-altering drugs or their equivalent, and threats to another of death, physical torture, or mind alteration.

Now, the United States, like any other state, can issue any treaty understandings it wishes, provided that they are not incompatible with the object and purpose of the treaty. ${ }^{46}$ Whether a partial, narrowing construction of the prohibition on mental torture is compatible with CAT's object and purpose is a debatable question—obviously, a partial prohibition on mental torture is better than nothing, even if it leaves a loophole for tortures that it is CAT's object and purpose to prohibit. Regardless of how one answers that question, however, such understandings have no effect on the content of international treaty law like CAT. ${ }^{47}$ Significantly, no other states-parties to CAT have adopted any similar narrowing definition of mental torture. On February 26, 1996 the Netherlands entered the following formal objection to the U.S. understanding just quoted: "The Government of the Kingdom of the Netherlands considers the

\footnotetext{
${ }^{45}$ Office of the United Nations High Commissioner for Human Rights, Convention Against Torture and Other Cruel, Inhuman or Degrading Treatment: Declarations and Reservations (2008)[hereinafter: CAT Declarations and Reservations], 11. http://www2.ohchr.org/english/bodies/ratification/9.htm [accessed 11/10/2008].

${ }^{46}$ Vienna Convention on the Law of Treaties (VCLT), art. 19(c) (limiting permissible reservations to those not "incompatible with the object or purpose of the treaty"). Although the United States describes its definition of "severe mental pain or suffering" as an understanding, not a reservation, it falls under the VCLT's definition of a reservation ("a unilateral statement, however phrased or named, made by a State, when signing, ratifying, accepting, approving or acceding to a treaty, whereby it purports to exclude or to modify the legal effect of certain provisions of the treaty in their application to that State") in Article 2(1)(d).

47 VCLT, art. 21(2): "The reservation does not modify the provisions of the treaty for the other parties to the treaty inter se."
} 
following understandings to have no impact on the obligations of the United States of America under the Convention: II. 1a This understanding appears to restrict the scope of the definition of torture under article 1 of the Convention."48 The next day, Sweden objected similarly: "It is the view of the Government of Sweden that the understandings expressed by the United States of America do not relieve the United States of America as a party to the Convention from the responsibility to fulfill the obligations undertaken therein." 49

The Dutch turned out to be right that the intention of the U.S. understanding was "to restrict the scope of the definition of torture"- specifically, as we have seen, to ward off labeling police brutality as torture. ${ }^{50}$ What has mattered is not the initial treaty understanding as such, but the repeated re-assertion of the same language in U.S. federal laws implementing the treaty. Apart from the injection of a general requirement for all torture of specific intent to inflict severe pain or suffering, which is another extremely important means of narrowing the scope of the behavior that counts as torture and to which we return below, the United States targets its fire directly at "mental pain or suffering," or psychological torture. As Assistant Attorney General Mark Richard said to the Senate Foreign Relations Committee in 1990, "It is ... in regard to the area of mental pain that the definition [of torture] poses the greatest problem."

\section{B. The Substitution Trick}

\footnotetext{
${ }^{48}$ CAT Declarations and Reservations, supra note 45, at 14 . We are grateful to Guy Goodwin-Gill for pointing out the prompt Dutch and Swedish objections to the U.S. understanding.

${ }^{49}$ Id., at 16.

${ }^{50}$ The George H. W. Bush Administration shared the Reagan Administration's worry that CAT might (in the eyes of some states) reach U.S. law enforcement practices: "The convention does place U.S. law enforcement officials when traveling overseas at risk of arrest and prosecution in foreign jurisdictions or even extradition to a third country for purported violations committed within the United States." Convention Against Torture: Hearing Before the S. Comm. on Foreign Relations, 101st Congress $2^{\text {nd }}$ Session (1991)[hereinafter: CAT SFRC Hearing](statement of Assistant Attorney General Mark Richard), S. Hrg. 101-718, Jan. 30, 1990, at 13.

${ }^{51}$ Id. at 12.
} 
The Senate employed two further means, beyond the specific intent requirement, in order to weaken the prohibition on psychological torture by shrinking the scope of what counts. One requirement imposes an allegedly necessary effect and the other imposes a very short list of allegedly necessary causes. Unless both the effect and one of the few specified causes are present, there is no severe mental pain or suffering and therefore no torture, regardless of how much mental agony the victim actually experienced.

Note first that the Senate understanding defines mental pain or suffering as "prolonged mental harm" ("mental pain or suffering refers to prolonged mental harm caused by or resulting from [etc.]"). This restrictive additional requirement is doubly arbitrary. What CAT prohibits is the infliction of mental torture; it contains absolutely no requirement that this infliction result in harm other than the pain or suffering itself. The U.S. understanding generates a requirement that would mean that the infliction of the severe pain or suffering, when it is psychological, is unobjectionable unless it has some prolonged additional effect. Or rather, it is unobjectionable because—reading the Senate's language carefully and literally_it isn't mental pain or suffering at all. "What is real about severe mental pain or suffering if it does not cause harm?" the U.S. seems to be asking. Further, the severe pain or suffering, when it is mental, must, in order to be objectionable, not only result in harm but the harm must be "prolonged." "What is wrong with severe pain or suffering, provided it is mental, if it does not cause harm that is prolonged?" is the full question. As Mark Richard objected to the Foreign Relations Committee about CAT's definition of torture, "mental suffering is often transitory, causing no lasting harm"—as though transitoriness means it is not really mental suffering. ${ }^{52}$

Could it be that the prolonged mental harm in this definition refers to the mental pain or suffering during the torture, rather than to an aftereffect? The answer is no, unless the torture

\footnotetext{
52 Id. at 17.
} 
itself is prolonged. The Senate's definition specifies that the only techniques that count as mental torture are physical torture, threats of a few specified kinds, and procedures like the administration of mind-altering drugs. None of these needs to be prolonged, and if they are not, "prolonged mental harm" can refer only to the aftereffects. To be sure, if prolonged drugging or prolonged physical torture generate severe mental suffering while they are going on, that could by itself count as prolonged mental harm under the Senate's definition even if it had no aftereffects; but that appears to be only a secondary meaning of the Senate's definition.

The Office of Legal Counsel interpreted the language to refer solely to aftereffects. The Bybee/Yoo Torture Memo explains "prolonged mental harm" this way:

For example, the mental strain experienced by an individual during a lengthy and intense interrogation — such as one that state or local police might conduct upon a criminal suspect—would not violate Section 2340(2). On the other hand, the development of a mental disorder such as posttraumatic stress disorder, which can last months or even years, or even chronic depression, which also can last of a considerable period of time if untreated, might satisfy the prolonged harm requirement. ${ }^{53}$

Thus, "For purely mental pain or suffering to amount to torture under Section 2340, it must result in significant psychological harm of significant duration, e.g., lasting months or even years." This is the interpretive exaggeration to which we earlier alluded. Correcting the exaggeration, the Levin Memo disagreed that the harm must last months or years, but Levin continued to deny that

\footnotetext{
${ }^{53}$ Bybee/Yoo Torture Memo, supra note 15, in COLE at 49. For a powerful critique of this argument, and the Bybee/Yoo construal of mental torture, see Kate Riggs, Richard Blakely, and Jasmine Marwaha, Prolonged Mental Harm: The Torturous Reasoning Behind a New Standard for Psychological Abuse, 20 HARV. HuM. RTS. J. 263 (2007).

54 Id. at 41 .
} 
the prolonged mental harm "is to be presumed any time one of the predicate acts occurs," and continued to insist that it "must extend for some period of time" to pass the legal threshold. ${ }^{55}$

Evidently, what in plain language would be called "mental pain or suffering" does not exist unless it actually produces prolonged mental harm as an aftereffect, and the aftereffect is the only mental pain or suffering the Senate understanding recognizes. The understanding retains words from CAT while assigning them a completely different reference, namely what would ordinarily be considered one of the possible effects of pain and suffering. If prolonged harm does not result, the pain or suffering never existed. We will refer to this as the substitution trick: the trick of substituting a possible effect for its cause so that the cause itself ceases to constitute torture. The result is the attempted erasure of any infliction of mental pain or suffering that does not leave behind harm -- in the case of psychological torture, prolonged harm -- in defiance of the fact that what CAT prohibits is severe mental pain or suffering.

\section{The Materialist Bias}

Notice that the law contains no corresponding requirement for physical pain or suffering — no claim that unless physical torture produces some additional effect like scarring or maiming, or, for that matter, prolonged mental harm, it is not pain or suffering. Of course, we have learned that U.S. interrogators in Iraq posted a placard in their interrogation chamber reading "NO BLOOD NO FOUL," but that cynical slogan meant only that torture that leaves no scars is hard to prove, not that it isn't torture. ${ }^{56}$ Claiming that it isn't torture would be too

\footnotetext{
55 Levin Memo, supra note 16, in COLE, supra note 15, at 145-46. Levin points out that cases under the Torture Victim Protection Act are consistent with this interpretation-some decisions point to persisting symptoms to find mental torture, while one case denies that a single night of death threats inflicted prolonged mental harm. Id. at 14748 (citing Villeda Aldana v. Fresh del Monte Produce, Inc., 305 F.Supp. 2d 1285, 1294-95 (S.D. Fla. 2003).

${ }^{56}$ Eric Schmitt \& Carolyn Marshall, In a Secret Unit's “Black Room," A Grim Portrait of Abuse, N.Y. Times, Mar. 19, 2006, A1. Task Force 6-26's “adage” was "If you don't make them bleed, they can't prosecute for it." Id.
} 
obviously incredible, given the notoriety of bloodless methods like water torture and electrical shocks. ${ }^{57}$ Somehow, though, requiring an additional, prolonged, harm seems less incredible in the case of mental torture, and the question is why. The implication is clear: the entire conception of psychological torture - the infliction of severe mental pain or suffering-must be viewed with suspicion. We will refer to this as the materialist bias in the U.S. position: the implication is that even desperate psychological distress is not quite as real as physical pain or suffering. ${ }^{58}$ To paraphrase Bertrand Russell's caricature of vulgar materialism, "Never mind, it's all matter." The materialist bias is our hypothesis to explain a number of the oddities in the law, including the specific substitution trick employed here. The generic form of the trick is the replacement of one thing by another; this specific instance is the replacement of the mental by the physical.

We can hear echoes of the materialist bias in the Bush Justice Department's treatment of physical suffering as well: the Bybee-Yoo torture memo denied that it exists separate from physical pain, but even when the Levin memo restored the category of suffering, it added a requirement that physical suffering be prolonged, which allowed the CIA to claim that waterboarding in short sessions is not torture. That requirement of extended duration has no basis in the torture statute and is in fact inconsistent with the torture statute. ${ }^{59}$ But apparently the memo's authors thought physical suffering that isn't pain isn't real unless it is prolonged, and therefore treated it on a par with mental pain and suffering. The materialist bias strikes again.

\footnotetext{
${ }^{57}$ See REJALI, supra note 13, at 65-401 for a comprehensive history of "clean" or "stealth" torture.

${ }^{58}$ Jacobs, supra note 20, at 167-68, points out the prevalence of the materialist bias.

${ }^{59}$ The memo read a requirement into the statute that physical suffering must be "of some extended duration" to constitute torture. Levin Memo, supra note 16, at 143. Not only is there no support for this requirement in the statute, the structure of the statute rules it out: under ordinary rules of statutory construction, the fact that the statute explicitly builds a duration requirement into the definition of mental torture but not physical torture means that there is no such requirement in the definition of physical torture: expressio unis est exclusio alteris. This flawed analysis, conjuring a statutory requirement out of thin air, proved convenient and indeed essential for permitting waterboarding: Levin's successor Stephen G. Bradbury used the Levin Memo's duration requirement to exclude waterboarding as a form of torture, because waterboarding sessions are short. Bradbury Techniques Memo, supra note 22, in COLE, supra note 15, at 193-94.
} 
The materialist bias dates back to the Reagan Administration's original submission of CAT to the Senate in 1988:

Mental pain and suffering is, however, a relatively more subjective phenomenon than physical suffering. Accordingly, when determining when mental pain and suffering is of such severity as to constitute torture, it is important to look to other, more objective, criteria such as the degree of cruelty and inhumanity of the conduct causing the pain and suffering. ${ }^{60}$

We want to acknowledge that one clause of the Senate's RUDs may, if correctly interpreted, escape distortion by the materialist bias. ${ }^{61}$ We saw above that among the enumerated possible causes of prolonged mental harm is "the administration or application ... of mind altering substances or other procedures calculated to disrupt profoundly the senses or the personality." This recognition that profound disruption of the senses or the personality is a significant mental harm could be an important tear in the veil obscuring mental phenomena. Everything turns on how broadly "the administration or application ... of other procedures calculated to disrupt profoundly the senses or the personality" can reasonably be construed. Although the statute does not explain what "other procedures calculated to disrupt profoundly the senses or personality" refers to, the category would surely include non-pharmaceutical interventions such as electrical stimulation of the brain, psychosurgery, and prolonged sensory deprivation. If the category were interpreted to include all psychological techniques designed to break the victim's personality, it would avoid the materialist bias that corrupts the remainder of the law. How expansively to read this clause is an important question to which we return very briefly below.

\footnotetext{
${ }^{60}$ S. Treaty Doc. No. 100-20, supra note 38 , at 3.

${ }^{61}$ We are grateful to Michael Froomkin for pointing this out.
} 


\section{The Four Causes}

The idea that mental pain and suffering must be defined by the kind of conduct that causes it brings us to the second way U.S. law minimizes the mental pain and suffering that can count as torture. The U.S. understanding of mental pain and suffering limits it to the mental pain and suffering arising from one of precisely four causes, and from nothing else.

Why such a short, exclusive list? Why should we suppose that severe mental pain or suffering could be caused in only four ways? The causes in the list quoted above are highly specific: use or threatened use of drugs or other mind-altering procedures, use or threat of physical torture, threats of the imminent death of the victim, and threats that someone other than the victim will imminently suffer death, physical torture, or administration of mind-altering drugs or something similar. The obvious question about these four required causes is: why precisely only these? What about a threat of imminent rape? What about being prevented permanently from performing required religious observances -- never allowed to pray properly, for example? What about being required to perform sexual acts considered perverse and disgusting? We see no good reason to think that only the few threats and actions that happen to be listed in the U.S. understanding can cause severe mental pain or suffering. The four causes enumerated in the law arbitrarily narrow what could count as mental pain or suffering and ignore most of the ways that interrogators standardly impose extreme psychological stress, such as prolonged isolation and sleep deprivation.

To see just how arbitrary this list is, and what latitude it gives interrogators, consider a threat that an interrogator made to Guantánamo detainee Mohamedou Ould Slahi, both in person and in writing, as described in an official military report: "U.S. authorities in conjunction with 
authorities from the country of origin of the subject ... would interrogate the mother of the subject.... The letter further indicated that if his mother was uncooperative she would be detained and transferred to U.S. custody at GTMO for long term detention." ${ }^{62}$ Analyzing this threat to the victim's mother, the report explains that it received legal approval:

As written the letter does contain a threat to detain the subject of the second special interrogation's mother but does not contain any threat on her life or that of her family.... [T]he Special Team Chief...claims that he cleared the plan with the senior judge advocate .... Considering the actual content of the letter, it is reasonable to conclude that the JAG advised that the letter was a proper deception and therefore additional approval was not required. ${ }^{63}$

The JAG was simply following the letter of the law, and the investigator concluded that the threat did "not rise to the level of torture as defined under U.S. law."64 Threats to kidnap and imprison your mother do not fall on the list of four causes, and therefore the mental suffering they induce cannot, under U.S. law, count as torture, no matter how agonizing the terror actually is.

The first of the four required causes is especially notable: mental pain or suffering can be caused by "the intentional infliction or threatened infliction of severe physical pain or suffering," that is, by physical torture or threats of physical torture. This seems designed to say: the only mental pain we are prepared to take seriously, apart from two or three special cases like the terror produced by threats of imminent death and the hallucinatory nightmares produced by mindaltering drugs, is mental pain produced by physical pain. Apart from a very few special cases,

\footnotetext{
${ }^{62}$ Schmidt Report, supra note 22, at 24.

63 Id. at $25-26$.

${ }^{64}$ Id. at 26.
} 
only physical pain really counts. "Do you claim to be undergoing mental suffering? Show me the physical pain that produced it." This is once again the materialist bias: if nothing is wrong with your body, nothing can be wrong with your spirit. ${ }^{65}$

Consider another threat made to Slahi:

Interrogator's colleagues are sick of hearing the same lies over and over and are seriously considering washing their hands of him. Once they do so, he will disappear and never be heard from again. Interrogator assured detainee again to use his imagination to think of the worst possible scenario he could end up in. He told Detainee that beatings and physical pain are not the worst thing in the world. After all, after being beaten for a while, humans tend to disconnect the mind from the body and make it through. However, there are worse things than physical pain. Interrogator assured Detainee that, eventually, he will talk, because everyone does. But until then, he will very soon disappear down a very dark hole. His very existence will become erased. His electronic files will be deleted from the computer, his paper files will be packed up and filed away, and his existence will be forgotten by all. No one will know what happened to him and, eventually, no one will care. $^{66}$

This horrifying threat, too, was deemed not to "rise to the level of torture under U.S. law"probably correctly, because of the materialist bias in the law, and because threats of oblivion are not threats of death, torture, or drugging. ${ }^{67}$

\footnotetext{
${ }^{65}$ For more on this general subject, see DEREK S. JEFFREYS, SPIRITUALITY AND THE ETHICS OF TORTURE (Palgrave Macmillan, 2009).

${ }^{66}$ Schmidt Report, supra note 22, at 25.

${ }^{67}$ Eventually U.S. District Judge James Robertson (in a classified opinion) ordered Slahi freed because the government lacked evidence to detain him. Gitmo Detainee Tied to 9/11 to be Freed, Military.com, Mar. 22, 2010, available at http://www.military.com/news/article/gitmo-detainee-tied-to-911-to-be-freed.html. The Court of Appeals for the District of Columbia remanded the case, and Slahi remains in custody. Oblivion may yet loom.
} 
Unfortunately, Congress wrote both the same required effect and the same required causes into the torture statute's provision on mental torture, without similarly imposing either a specific effect or a specific cause on physical pain or suffering. There is no plainer example of the materialist bias: mental pain and suffering are made much more difficult to demonstrate than physical. There is only slight verbal difference between the torture statute and the Senate's understanding of CAT. Where the latter makes prolonged mental harm resulting from the four enumerated causes the definition of "mental pain or suffering," the statute makes it the definition of "severe mental pain or suffering.," ${ }^{68}$ Arguably this is a slight improvement, because it might be taken as a gloss on the meaning of 'severe' rather than the meaning of 'mental pain or suffering' - but it still radically redefines 'severe mental pain or suffering' to mean one of its possible effects: prolonged mental harm. Consequently, inflicting mental pain or suffering themselves are not prohibited! All that U.S. law prohibits is prolonged mental harm caused in a few arbitrarily specified ways, not all the infliction of severe mental pain or suffering prohibited by international law. Through the substitution trick, the possible effect, the harm, has replaced the cause, the infliction of the mental pain and suffering.

The torture statute uses the same list of four possible causes of 'severe mental pain or suffering' that were presented in the Bush I-era ratification understanding accepted by the Clinton Administration. Someone who was simply caused severe mental pain or suffering in the ordinary sense of these words by any means other than the four listed would not count as having been tortured. This, we fear, is precisely the point.

${ }^{68} 18$ U.S.C. $\$ 2340(2)$. 
Congress allowed the same fallacies to infect the U.S. war crimes statute, which also prohibits torture. ${ }^{69}$ The war crimes statute was enacted in 1996 to (belatedly) implement the 1949 Geneva Conventions, just as the torture statute was enacted to implement CAT. Torture can of course be practiced outside the context of war. Many governments torture their own citizens when there is no war. But torture of adversaries during an armed conflict was recognized as a war crime long before CAT. The Geneva Conventions recognize torture during an international armed conflict as a "grave breach" that must be criminalized; ${ }^{70}$ they also include an article (known as "common Article 3" because it appears under that number in all four Geneva Conventions) that prohibits torture and outrages to human dignity in non-international armed conflicts as well. In its original version, the U.S. war crimes statute prohibited all grave breaches and all violations of common Article 3. However, after the Supreme Court's 2006 Hamdan decision, ${ }^{71}$ which declared that common Article 3 applies to the U.S. conflict with Al Qaeda and the Taliban, Congress weakened the statute by decriminalizing two clauses of common article 3 , one prohibiting unfair trials and one prohibiting outrages on human dignity. Congress decriminalized them retroactively to the putative beginning of the "war on terror"- one of three statutes designed to ensure that U.S. personnel who had abused detainees would not be held accountable. ${ }^{72}$ This was part of the 2006 MCA, and Congress left the weakening of the war

\footnotetext{
6918 U.S.C. $\$ 2441$.

70 The four Geneva Conventions of August 12, 1949, 75 U.N.T.S. 31, 85, 135, 287, usually abbreviated 'GCs' and designated by their number, define 'grave breaches' in GC I, art. 50; GC II, art. 51; GC III, art. 130; and GC IV, art. 147; all these definitions include torture as a grave breach. The four GCs all require the parties to "undertake to enact any legislation necessary to provide effective penal sanctions for persons committing, or ordering to be committed, any of the grave breaches of the present Convention. . .." GC I, art. 49; GC 2, art. 50; GC III, art. 129; GC IV, art. 146. These articles also make grave breaches universal jurisdiction offenses.

${ }^{71}$ Hamdan v. Rumsfeld, 548 U.S. 557 (2006).

72 "The amendments made by this subsection ... shall take effect as of November 26, 1997..." Act Oct. 17, 2006, P.L. 109-366, §6(b)(2), 120 Stat. 2635. To further ensure impunity for U.S. torturers, Congress stripped jurisdiction from the federal courts over "action against the United States or its agents relating to any aspect of the detention,
} 
crimes statute intact in the 2009 MCA. Again, we see changes in the substantive criminal law the purpose of which is screening U.S. officials from potential liability rather than improving the definitions in the law.

Even with this modification, at first glance the war crimes statute seems to have taken a giant step forward compared to the torture statute. As we have explained above, the latter redefines severe mental pain or suffering as one of its possible effects, namely "prolonged mental harm caused by or resulting from ... [only the usual four sources].” The war crimes statute, by contrast, seems to have the distinct merit of returning to the standard practice of keeping cause and effect separate, defining torture as "the act of a person who commits, or conspires or attempts to commit, an act specifically intended to inflict severe physical or mental pain or suffering .....,73

Unfortunately, these appearances are deceiving, because the drafters define severe mental pain or suffering by reference to the definition in the torture statute. So the real definition of torture in the war crimes statute now is: an act specifically intended to inflict prolonged mental harm (but only from one of the usual four sources). ${ }^{74}$ Once again, the mental pain or suffering

transfer, treatment, trial, or conditions of confinement of an alien who is or was detained by the United States and has been determined by the United States to have been properly detained as an enemy combatant or is awaiting such determination." Id., 120 Stat. 2635. A year earlier, in the Detainee Treatment Act of 2005, Congress enacted an impunity provision entitled "Protection of United States Government personnel engaged in authorized interrogations," which specifies that "it shall be a defense that such officer, employee, member of the Armed Forces, or other agent did not know that the practices were unlawful and a person of ordinary sense and understanding would not know the practices were unlawful. Good faith reliance on advice of counsel should be an important factor, among others, to consider in assessing whether a person of ordinary sense and understanding would have known the practices to be unlawful." 42 U.S.C. $\$ 2000 d d-1(a)$.

7318 U.S.C. $\$ 2441$ (d)(1)(A).

${ }^{74}$ See also President Bush's Executive Order 13440 (July 9, 2007), interpreting the meaning of Common Article 3 and its applicability to the CIA. Section 3(b)(i)(A) defines 'torture' using the torture statute 18 U.S.C. §2340, while Section 3(b)(i)(B) adds 'torture' as defined in the war crimes statute 18 U.S.C. §2441(d) (both incorporating the same flawed definition of mental torture). President Bush's Executive Order does make some progress, by classifying "willful and outrageous acts of personal abuse done for the purpose of humiliating and degrading an individual" as well as "acts intended to denigrate the religion, religious practices, or religious objects of the individual" as violations of Common Article 3. Sections 3(b)(i)(E) and (F). These are forms of psychological torture, 
itself has completely disappeared, having been redefined as the harm that sometimes results from mental pain or suffering.

As mentioned earlier, the four causes would not be so narrow as they have tended to be assumed to be if the second cause, "the administration or application, or threatened administration or application, of mind altering substances or other procedures calculated to disrupt profoundly the senses or the personality," were interpreted to include all systematic procedures designed to produce profound disruption of the personality. Why shouldn't "other procedures calculated to disrupt profoundly the senses or the personality" include, for example, the careful contrivance of prolonged isolation and sleep deprivation frequently employed in Guantánamo? Reading the language inclusively would go part way toward redeeming the RUDs and the torture statute, although the statute would still gratuitously require prolonged mental harm as an aftereffect.

Sadly, psychological torture can in fact be counted on to cause harm, which is indeed often severe and prolonged. Even worse, substantial research suggests that psychological torture, as well as some cruel and inhuman treatment that might not qualify as torture at all, can cause more severe long-term damage than some physical torture tends to. ${ }^{75}$ But it is important to understand that neither of these facts cures the fundamental confusion of replacing mental

and it is noteworthy that the Order prohibits them, although it does not call them torture. It is unclear whether the Order would find that the sexual humiliations visited on Al Qahtani, like dressing him in a bra, calling his mother a whore, and stripping him naked in front of women, would be prohibited: the test is whether they are "so serious that any reasonable person, considering the circumstances, would deem the acts to be beyond the bounds of human decency, such as sexual or sexually indecent acts undertaken for the purpose of humiliation, forcing the individual to perform sexual acts or to pose sexually, [or] threatening the individual with sexual mutilation..."

${ }^{75}$ See Metin Basoglu, Maria Livanou, and Cvetana Crnobaric, Torture vs Other Cruel, Inhuman, and Degrading Treatment, 64 ARCHIVES OF GENERAL PSYCHIATRY 277 (2007), and Metin Basoglu, A Multivariate Contextual Analysis of Torture and Cruel, Inhuman, and Degrading Treatments: Implications for an Evidence-Based Definition of Torture, 79 AM. J. ORTHOPSYCHIATRY 135 (2009). We do not, however, accept the implication of the latter paper that the established international definitions, as distinguished from the arbitrary U.S. definitions, require change. See also THE TRAUMA OF PSYCHOLOGICAL TORTURE, supra note 20. 
suffering by its aftereffects. Moreover, the substitution trick requires prosecutors to prove not only that a victim was psychologically damaged in the aftermath of torture, but that the torture caused the damage. Proving causation is notoriously difficult in injury cases where the victim's damage may have multiple causes, so that the substitution trick creates a needless hurdle to the prosecution and deterrence of torture.

\section{E. Limiting Torture to the Handiwork of Sadists}

Yet the strongest objection to insistence on resultant prolonged harm is its contribution to creating an impossibly high threshold for any action to qualify as torture. Besides

(1) the insistence for the case of mental torture on harm being prolonged (reflecting, we think, the materialist bias) and

(2) the substitution trick, performed in the torture statute and incorporated by reference into the war crimes statute,

Congress also preserves one other noxious element from the ratification understanding:

(3) the claim, mentioned much earlier but not examined until now, that only if the torturer specifically intends the prolonged harm does his act constitute torture.

The torturer must specifically intend to inflict "severe physical or mental pain or suffering," but since the quoted phrase has been re-defined to mean "prolonged mental harm," he must actually (i) intend to produce and (ii) produce prolonged mental harm. This is an absurd requirement. Only a sadist would inflict severe mental pain or suffering with the intention of inflicting prolonged mental harm. A “normal," i.e. non-sadistic, torturer whose goal was to extract information that would prevent a terrorist attack, would not care what became of his victim after the information was obtained. He would have no reason to intend to leave the source of the 
information with prolonged mental harm unless he were sadistic or had some special hatred for his victim. But to require sadism or hatred as a necessary condition of counting the infliction of severe mental pain or suffering as torture is a ridiculously narrow definition of psychological torture, excluding most of what would be included in the category on any commonsense understanding or on the international legal understanding.

All this definitional legerdemain has the result that a torturer who specifically intends to inflict mental pain or suffering, as his means, but does not further intend as a goal that the pain or suffering should result in prolonged mental harm is not committing torture as defined under U.S. law. The law has defined away all psychological torture that is not the handiwork of sadists. Torture is not what we think it is: not pain, but prolonged results of pain. And torturers are not people who inflict severe pain for the sake of, say, extracting information: someone is a torturer only if he specifically intended the pain to result in prolonged harm. These laws are utterly untrue to the nature of torture. Congress ought to repeal these flawed and narrow characterizations of psychological torture before many more torturers stride through the gate that Congress has flung wide open.

\section{The Forensic Fallacy}

Before accepting this critique, however, we must consider a possible response. Congress was writing a criminal law carrying heavy penalties. Elementary considerations of due process, embodying the principle of legality accepted worldwide (nulla crimen sine lege), require precision in drafting criminal statutes, to ensure they have defined elements susceptible to proof or disproof in a court of law. That is how the Clinton Administration explained its understanding of mental torture in its 1999 report to the UN's Committee Against Torture: 
The intentional infliction of "mental" pain and suffering is appropriately included in the definition of "torture" to reflect the increasing and deplorable use by States of various psychological forms of torture and ill-treatment such as mock executions, sensory deprivations, use of drugs, and confinement to mental hospitals. As all legal systems recognize, however, assessment of mental pain and suffering can be a very subjective undertaking. There was some concern within the U.S. criminal justice community that in this respect the Convention's definition regrettably fell short of the constitutionally required precision for defining criminal offenses. To provide the requisite clarity for purposes of domestic law, the United States therefore conditioned its ratification upon [the Senate's understanding quoted above]. ${ }^{76}$

This was the same rationale that Assistant Attorney General Mark Richard gave to the Senate Foreign Relations Committee hearing on CAT in 1990:

The basic problem with the convention, one that permeates largely all of our concerns at the Department of Justice, is its imprecise definition of torture, especially as that term is applied to actions which result solely in mental anguish. This definitional vagueness makes it doubtful that the United States can, consistent with constitutional due process constraints, fulfill its obligation under the convention to adequately engraft the definition of torture into the domestic criminal law of the United States. ${ }^{77}$

\footnotetext{
${ }^{76}$ U.S. Dep't of State, Initial Report of the United States of America to the UN Committee Against Torture, Oct. 15, 1999, available at http://www.state.gov/www/global/human_rights/torture_articles.html (accessed Dec. 18, 2010), Part II, Articles 1 and 2(A)(a).

${ }^{77}$ CAT SFRC Hearing, supra note 50 (statement of Assistant Attorney General Mark Richard), at 12. State Department Legal Adviser Abraham Sofaer offered the same explanation: "If the Convention were simply a political statement, imprecision would cause no difficulties. However, because the Convention is a legal instrument and creates legal obligations, and especially because it requires establishment of criminal penalties under our domestic law, we must pay particular attention to the meaning and interpretation of its provisions, especially concerning the standards by which the Convention will be applied as a matter of U.S. law.” Id. at 8.
} 
He added: "Mental pain is by its nature subjective. Action that causes one person severe mental suffering may seem inconsequential to another person.",78

Superficially, this argument has some merit. What is to prevent someone from falsely claiming that her mental suffering was severe when it actually was not? It's just her word against the defense about what she experienced. Requiring a showing of prolonged mental harm, for example a clinical diagnosis of depression or PTSD, provides the kind of independent evidence that a court of law can evaluate. Similarly, limiting the acts constituting mental torture to a small set that everyone can recognize as what the Reagan Administration called a "deliberate and calculated act of an extremely cruel and inhuman nature" diminishes the possibility of wrongful convictions.

But on closer inspection, the argument fails. For one thing, the kinds of evidence that might show severe mental pain or suffering are hardly anomalies in courts of law: they will include, for example, third party observations of the victim's behavior, evidence by expert psychologists who have observed large numbers of torture victims, and conceivably testimony by others who have experienced the same forms of abuse. If witnesses testify credibly that they observed a detainee lying on the floor in a pile of his own hair which he had pulled out, or publicly "masturbating like a monkey in the zoo"—as agents reported from Guantánamo and a CIA "black site"- that seems like an objective indicator of severe mental suffering. ${ }^{79}$ So too when a "detainee threw himself on the floor and began banging his head" because his Guantánamo interrogator rubbed red ink on his shoulder and told him it was her menstrual blood. ${ }^{80}$ This too seems like objective evidence of a subjective state, fully open to a court to

\footnotetext{
${ }^{78}$ Id. at 17.

${ }^{79}$ See text accompanying notes 100-101, infra.

${ }^{80}$ Schmidt Report, supra note 22, at 8.
} 
evaluate. As for the victim's own testimony, juries assess witness credibility every day, including disputed testimony that cannot be corroborated by other sources, like a date rape victim's testimony that she never consented to sex.

Notice that in physical torture cases juries would be compelled to make an equally "subjective" determination about whether physical pain or suffering was severe enough to count as torture. Of course there might be borderline cases (is a belly slap torture?), but importantly there might be clear cases as well. To regard the severity of mental suffering as more subjective than the severity of physical suffering is simply the materialist bias.

So too, jurors apply broad standards, like the "reasonable person" standard, every day in courts of law. They do it in the obvious way: they put themselves in the shoes of a reasonable person and ask themselves what they would do if they were in the situation. This kind of exercise in imaginative identification with another person is the everyday work of jurors and judges. Evaluating the severity of suffering is no different. Would jurors think that partial drowning is severe suffering? Would they think so after hearing testimony from former Navy SEALs who were waterboarded in survival training and who say "yes, it was torture" (or "no, it wasn't all that bad")? This is not much different, and not notably less subjective, than whether weeks of sexual humiliations or solitary confinement cause severe mental suffering.

In any case, the worry about subjectivity and false accusations doesn't explain why the prohibited forms of mental torture are just the four listed in the statute, or why "prolonged mental harm," which the law requires fact-finders to evaluate, is any less subjective a category than severe mental pain or suffering. The legal solution simply doesn't match the problem it purports to solve, and the argument simply doesn't show that the problem is a real one. 
Finally, both the problem and the solution seem tailored for a specific political purpose: screening the United States from the political embarrassment of having official practices labeled 'torture'. Legal Adviser Sofaer explained to the Senate that one concern about CAT was the possibility of accusations against U.S. law enforcement personnel. "We believe that such complaints are likely to be frivolous, and aimed at embarrassing the United States rather than at rectifying the form of injustice with which the Convention was intended to deal." ${ }^{" 81}$ This, however, is a public relations concern, not a due process concern.

Earlier, we saw that the Reagan Administration had raised worries about excessive subjectivity in the concept of mental torture because of potential accusations of torture in cases of police brutality. By the time of the Clinton Administration, these concerns had spread from police to prisons because of the European Court of Human Rights's decision in the 1989 Soering case, which declared that confinement in a U.S. death row violates the European Convention on Human Rights prohibition of torture and inhuman or degrading treatment. ${ }^{82}$ The opinion generated consternation and outrage in the U.S. government, because it treated a psychological experience—-the so-called "death row phenomenon"—as in effect a form of torture. Soering played a role as the State Department shepherded CAT through the Senate. ${ }^{83}$ Of course, CAT

\footnotetext{
${ }^{81}$ Id. at 9.

82 Soering v. United Kingdom, 11 Eur. Ct. H.R. (ser. A) (1989). In Soering, the European Court prohibited the extradition of a German teen-ager to face capital charges in Virginia- he and his girlfriend were charged with murdering her parents - because of the "death row phenomenon" of psychological suffering as the inmate awaits execution. The Court found it to violate Article 3 of the European Convention on Human Rights, the prohibition on torture and inhuman or degrading treatment. (For legal reasons, the European Court could not find that the death penalty itself violates the European Convention on Human Rights.)

${ }^{83}$ So we were told by David P. Stewart, who as an attorney adviser in the State Department's Legal Advisers Office was charged with shepherding CAT through the Senate. According to Abraham D. Sofaer, the State Department's Legal Adviser in the George H.W. Bush Administration, the U.S. RUDs concerning cruel, inhuman, or degrading treatment were inserted in response to Soering. Statement of Abraham D. Sofaer, Hearing Before the Foreign Relations Committee, United States Senate, $101^{\text {st }}$ Cong., $2^{\text {nd }}$ session, S. Hrg. 101-718, Jan. 30, 1990, at 11; see also Mr. Sofaer's response to Sen. Frank Murkowski, id. at 39 (stating that "The decision in the Soering case ... is just unreasonable, we believe, and we do not adhere to it, and we will never adhere to it.")
} 
does not apply only to U.S. officials; indeed, because the statute is limited to torture committed outside U.S. territory, it will apply pre-eminently to torture committed by others. ${ }^{84}$ So far, the only prosecution under the torture statute is that of "Chuckie" Taylor, the son of former Liberian President Charles Taylor. But this fact itself highlights how political the focus on U.S. public relations issues is - far removed from a good faith dispassionate concern about due process for defendants.

But suppose we agree that Congress might justifiably tighten up CAT's definitions for due process reasons. That would have nothing to do with the correct definition of mental pain or suffering. Thinking otherwise is what we call the forensic fallacy: confusing the due process requirement of narrowness and precision in criminal statutes with defining features of torture.

The result of the forensic fallacy is that concepts of right and wrong are weakened. Then there is a baleful feedback effect: the criminal law definition, cramped and narrowed, now becomes the "legal definition" more generally, and then the policy definition. In 2006, President George W. Bush stated, "I want to be absolutely clear with our people, and the world: The United States does not torture. It's against our laws, and it's against our values. I have not authorized it -- and I will not authorize it." ${ }^{85}$ The President was echoing a similar statement he made soon after Abu Ghraib, that "America stands against and will not tolerate torture. ... Torture is wrong wherever it occurs, and the United States will continue to lead the fight to

\footnotetext{
${ }^{84} 18$ U.S.C. $\$ 2340$ (A) (a) makes clear that the crime of torture being created under U.S. law applies only to acts "outside the United States". The rationale for this restriction is supposed to be that torture committed inside the United States had already been criminalized by various other laws even if not under the name of torture. This assumes that these various U.S. laws embody an understanding of torture that is the same as or superior to the understanding in the international documents, an assumption that we find highly dubious. The torture statute applies whenever "(1) the alleged offender is a national of the United States; or (2) the alleged offender is present in the United States, irrespective of the nationality of the victim or alleged offender". 18 U.S.C. §2340A (b).

${ }^{85}$ President Discusses Military Commissions to Try Suspected Terrorists, The White House, Sept. 6, 2006, available at http://georgewbush-whitehouse.archives.gov/news/releases/2006/09/20060906-3.html (accessed Jan. 30, 2011).
} 
eliminate it everywhere." ${ }^{, 6}$ And yet President Bush fully acknowledges that he authorized the CIA's techniques and would do it again. ${ }^{87}$ Apparently "the United States does not torture" means that the United States does not do anything that the torture statute (as interpreted by administration lawyers) criminalizes. Ironically, criminalizing mental torture-which CAT requires, and which seems like the obvious civilized thing the law should do-leads us to misunderstand what torture is. This, in turn, feeds back to affect the law. When the Office of Legal Counsel withdrew the Bybee Torture Memo, the Levin Memo that replaced it conspicuously declined to address two of its most radical conclusions: that the president's commander-in-chief authority allows him to override criminal statutes, and that the self-defense and necessity defenses are available to accused torturers. Rather than replacing the Bybee-Yoo arguments with a better analysis, Levin ducked the issues because "[c]onsideration [of these issues] ... would be inconsistent with the President's unequivocal directive that United States personnel not engage in torture." 88 And yet as he wrote these words, Levin was perfectly aware of the mental and physical tortures that the Bybee Techniques Memo had approved, and his memo also approves them. ${ }^{89}$ The forensic fallacy corrupts the extra-legal concept of torture, and that leads to corruption of the law itself.

Another example of the forensic fallacy appears in removal cases in which someone facing deportation petitions for relief under CAT because they will be subjected to severe pain or suffering in the brutal prisons of their country of origin. ${ }^{90}$ Courts denying relief to Haitians have

\footnotetext{
${ }^{86}$ Statement on United Nations International Day in Support of Victims of Torture, 40 Weekly Comp. Pres. Doc. 1167-68 (July 5, 2004).

${ }^{87}$ GeOrge W. Bush, Decision PoInTs 171 (2010).

${ }^{88}$ Levin Memo, supra note 16, reprinted in COLE, supra note 15, at 130.

${ }^{89}$ Id. at 130, n. 8.

90 Article 3 of CAT prohibits states from returning someone to a state where "there are substantial grounds for believing that he would be in danger of being subjected to torture"; Congress implemented Article 3 in the Foreign
} 
focused on the specific intention requirement in the torture statute and concluded that even if "severe pain was the 'only plausible consequence' of a petitioner's imprisonment in a Haitian prison" this would not constitute torture because the petitioner cannot show that officials specifically intend to inflict severe pain or suffering on him; thus the petitioner gets no CAT protection. ${ }^{91}$ But the specific intent requirement was inserted in U.S. law for due process reasons, and to regard a protection in criminal prosecution as a defining feature of torture in the question of removal is the forensic fallacy—doubly so, because the U.S. specific intent requirement is significantly narrower than the mens rea element in Article 1 of CAT. ${ }^{92}$

\section{Grasping Why Inflicting Mental Pain and Suffering Ought to be Illegal}

We are so far only assuming, of course, the reasonableness of the international consensus that psychological torture is to be absolutely prohibited just as physical torture is. But is psychological torture really that bad? We need first to remember one of the respects in which all torture, physical and psychological, is especially awful. It is common for people to say that "of course" being killed is far worse than being tortured. Being killed must be terrible -- we hope

Affairs Reform and Restructuring Act ("FARRA"). See Pub. L. No. 105-227, Div. G, Tit. XXII, § 2242, 112 Stat. 2681, 2681-761, 2681-822 (codified as a note to 8 U.S.C. $\$ 1231$ ).

${ }^{91}$ Pierre v. Attorney General of the United States, 528 F.3d 180, 184 (3d Cir. 2008)(en banc)(quoting Lavira v. AG of the United States, 478 F.3d 158, 170 (3d Cir. 2007)); see also Auguste v. Ridge, 395 F.3d 193 (3d Cir. 2005); Matter of J-E, 23 I. \& N. Dec. 291 (BIA 2002).

92 Article 1 of CAT uses "intentionally" where 18 U.S.C. $\$ 2340$ uses "specifically intended." "Intentionally" does not have the same meaning in all legal systems; as State Department Legal Adviser Abraham Sofaer notes, "The Convention was negotiated on a multilateral basis, ... and differing points of view and differing legal systems are necessarily reflected in the final text." Sofaer statement, at 8. In the German legal system, "intention" (Vorsatz) is a significantly broader concept than specific intent, or even intention as defined in the Model Penal Code. Vorsatz includes not only U.S.-style intention (dolus directus, in German terminology) and specific intent (dolus specialis), but also dolus eventualis, the nearest German equivalent to recklessness. Dolus eventualis means acting in awareness of an unjustifiable risk, and being reconciled to that risk. Greg Taylor, Concepts of Intention in German Criminal Law, 24 OXFORD J. LEG. STUDIES 99, 101-06 (2004). Arguably, under this broader concept of intention, the brutal conditions in Haitian prisons may well count as torture under CAT. The German jurisprudence is widely influential in Europe and Latin America, and the International Criminal Court has interpreted "intention" in the German meaning, to include dolus eventualis. Prosecutor v. Lubanga, Case No. ICC-01/04-01/06, Decision on the Confirmation of Charges (Jan. 29, 2007), §352. 
never to be killed. But torture has its own special terrors. People also often say that what they fear is not so much death but dying. It is one thing to have gone, it is another to continue to survive but in despair and with no grounds for hope. One of the special terrors of torture is that like dying, as distinguished from death, being tortured is a continuing process, not a single event or a final state. It is a process filled with dread, despair, hopelessness, and the awful awareness that one has absolutely no control over one's own condition. One can try to end the torture by trying to cooperate, but the torturer may well not be convinced and may well not admit it even if he is. Like the flies to the wanton boys, and like us to the gods, in the words of Shakespeare's blinded Gloucester quoted at the beginning, the victim is the torturer's plaything. The vulnerability is absolute, and the mental suffering accompanying that awareness is awful.

One is of course rarely in full control of one's fate -- the panic at the recent world financial crisis in part reflected many people's frightening sense of having lost any firm grip on how their lives would go in future. But the fear of a depleted pension is nothing to the fear that one's own self will be undermined so that one will not retain even the underlying psychological integrity necessary for having desires and beliefs that are one's own, much less the psychological capacity (the agency) to act effectively on them -- that one will be returned to the infantile state of being an uncoordinated bundle of desires and fears with no integral self to organize them.

Think of a practice other than torture that is utterly wrong and ought universally to be prohibited -- say, slavery. The slave is at the mercy of her owner. She works when and where he says. She gives him sexual pleasure when and where he says. But even slave owners were never believed even by defenders of slavery to be entitled to engage in the unlimited torture of the slaves. Slaves are at the mercy of their owners to an extreme degree, but even slavery recognized a limit not acknowledged by psychological torture. In one sense slaves clearly have 
their spirits broken; they are subject to the lash and to the market in persons. Living in fear of being whipped or sold away from their family and loved ones, they learn to give up much hope of fulfilling their dreams and goals. But their personality structures remain intact so that they are capable of having dreams and goals that are meaningfully their own, even if they are virtually certain that they will never actualize them. ${ }^{93}$

Psychological torture, in contrast, undermines the structure of the personality -- it literally breaks apart the self, unhinging its parts from each other. The victim is reduced to a quivering bundle of fears, driven to try to please, that is, to try to fulfill the wishes of others, with few wishes of her own, except release from the awful psychological stresses that are being systematically and relentlessly imposed by all-powerful others. This goes far beyond what slavery involved and gives new meaning to being at the mercy of someone else.

This complete breaking of the spirit is the goal of psychological torture, the distinctive methods of torture now widely practiced: the breaking of "resistance," i.e. the self, and rapid "regression" to a childlike state of pure desire to please those who completely control one's fate, one's torturers. ${ }^{94}$ Is this worse than death? It hardly matters because it is too terrible to be permitted, much less to have been adopted as state policy and protected by legal fallacies, as it now has in the United States.

Consider just a few concrete examples of what following the basic CIA paradigm means. ${ }^{95}$ A memo from a shocked FBI agent at Guantánamo to the Office of General Counsel of the FBI on 2 August 2004 said the following:

\footnotetext{
${ }^{93}$ Many slave songs clearly express both the dreams and the painful awareness that they almost certainly never will be.

${ }^{94}$ MCCOY, A QUESTION OF TORTURE, supra note 10, ch. 2.

${ }^{95}$ We are not suggesting the psychological torture illustrated below was carried out by CIA agents. Rather it was carried out by people who had become convinced that the CIA paradigm is modern, scientific, and superior. How
} 
As requested, here is a brief summary of what I observed at GTMO. On a couple of occassions [sic], I entered interview rooms to find a detainee chained hand and foot in a fetal position to the floor, with no chair, food, or water. Most times they had urinated or defecated on themselves, and had been left there for 18-24 hours or more. On one occassion [sic], the air conditioning had been turned down so far and the temperature was so cold in the room, that the barefooted detainee was shaking with cold. When I asked the MP's what was going on, I was told that interrogators from the day prior had ordered this treatment, and the detainee was not to be moved. On another occassion [sic], the $\mathrm{A} / \mathrm{C}$ had been turned off, making the temperature in the unventilated room probably well over 100 degrees. The detainee was almost unconscious on the floor, with a pile of hair next to him. He had apparently been literally pulling his own hair out throughout the night. On another occassion [sic], not only was the temperature unbearably hot, but extremely loud rap music was being played in the room, and had been since the day before, with the detainee chained hand and foot in the fetal position on the tile floor. ${ }^{96}$

This FBI agent is describing techniques, such as chaining on the floor in a fetal position and being allowed to lie in one's own excrement, designed to reduce victims to an infantile state. At least one victim, who seems to have been pulling out his own hair during the night, seems to have been reduced to some such sub-adult state.

this model came to be adopted in recent years even by some people in the U.S. military, which has a strong tradition of opposition is torture in general and psychological torture in particular, is a tangled story that cannot be repeated here. McCoy goes most thoroughly into the techniques themselves and famous psychologist Donald O. Hebb's theory of regression to an infantile state, on which they rest (see previous note), but also see MAYER, supra note 24; PhILIPPE SANDS, TORTURE TEAM: DECEPTION, CRUELTY AND THE COMPROMISE OF LAW (2008); and essays in OJEDA, supra note 20 .

${ }^{96}$ FBI Memo (2004), 1. http://www.aclu.org/torturefoia/released/FBI_5053_5054.pdf (accessed 2 October 2008). Large numbers of similar memos are available in Jameel Jaffer and Amrit Singh, Administration of Torture: A Documentary Record from Washington to Abu Ghraib and Beyond (New York: Columbia University Press for ACLU, 2007). 
McCoy reports the following about the interrogation at Guantánamo of "Detainee 063" [Mohammed al-Qahtani]: "Playing upon Arab attitudes toward dogs, the Guantánamo guards, in their [interrogation log] entry for December 20, 2002, wrote: 'began teaching the detainee lessons such as stay, come, and bark to elevate his social status up to that of a dog. Detainee became very agitated." ${ }^{97}$ This was at 11:15 a.m. At 10:00 p.m. the same day he is forced to stand naked in front of female interrogators on the pretext that he needs to be strip-searched: "The detainee was strip-searched. Initially he was attempting to resist the guards. After approximately five minutes of nudity the detainee ceased to resist.... He stated that he did not like the females viewing his naked body while being searched and if felt [sic] that he could have done something about it then he would have ..."98

Philippe Sands summarizes in chilling detail the treatment of Detainee 063 over an early two-day period (days 11 and 12 of the 51 days of intense interrogation), which included being forced to view 'girly' magazines that he found offensive, forced to stand and face the American flag while the national anthem was played, and denied permission to pray. ${ }^{99}$ On January 11 , 2003, the fiftieth straight day of interrogation, usually for twenty hours per day, the interrogation log says:

Source received haircut. Detainee did not resist until the beard was cut. Detainee stated he would talk about anything if his beard was left alone. Interrogator asked detainee if he would be honest about himself. Detainee replied 'if God wills'. Beard was shaven. A

\footnotetext{
${ }^{97}$ MCCOY, supra note 10, at 128. For an official account of the interrogation tactics used on this prisoner, see the Schmidt Report, supra note 22, at 13-21.

${ }^{98}$ SANDS, supra note 95, at 127.

${ }^{99}$ Id. at 14
} 
little water was poured over the detainee's head to reinforce control and wash the hair off. Interrogator continued the futility approach. The detainee began to cry when talking. ${ }^{100}$ All this relentless sexual and religious humiliation, was designed to demonstrate to the victim his utter powerlessness -- "futility" -- and undermine his sense of self, his sense of being an autonomous agent who could have and act on his own beliefs, such as covering himself in the presence of women and praying when he believed he should. It is completely incredible, we think, that reducing a person to such a state of powerlessness and inflicting him with the painful awareness that he has beyond all doubt been brought so low -- he cannot even keep his clothes on when he believes it is shameful to have them off -- does not count as torture unless, in addition to suffering the state itself, the person also suffers some other prolonged harm (and indeed suffers it because the prolonged harm was specifically intended to be the result of the destruction of agency).

As a result of his torture, which included strong elements of psychological torture, in one of the CIA's black sites, Abu Zubayda, the purported Al Qaeda logistics chief [real name: Zayn al-Abidin Muhammed Hussein] had evidently been caused to regress at least temporarily to a juvenile state:

As one former CIA officer put it, and another confirmed, "He spent all of his time masturbating like a monkey in the zoo. He went at it so much, at some point I heard he injured himself. They had to intervene. He didn't care that they were watching him. I guess he was bored, and mad." Another source said, "He masturbated constantly. A couple of guards were worried about it..... This was closed circuit. He complained to the

\footnotetext{
${ }^{100}$ Id. at 191.
} 
interrogator that he would never have the chance to feel a woman's touch again, and lament that he would never have children." 101

This is a man who has been driven into desperate despair --broken, left with no shame and only a pitiful desire repeatedly to perform one of the few pieces of effective behavior still allowed to him.

Part of the special wrongfulness of torture lies, then, in the limitlessness of the extent to which the victim is at the mercy of the torturer, who never relents until he himself, for his own reasons, chooses to end the terror which this implants in the victim. The victim can attempt to end the torture by trying to give the torturer what the victim thinks the torturer wants, but the torturer decides entirely for himself what he wants at any given time and whether he believes he has it all. The victim may well guess wrong about what the torturer wants, and often the victim does not have what the torturer wants in any case, especially of course if the victim is not who the torturer thinks he is or has not done what the torturer suspects he has done. All power remains with the torturer, who may move the goal posts as often and as far as he wishes. The victim is utterly at his mercy. Unlike even war, torture has no natural end. It ends when the torturer chooses to end it. The tyranny of torture is absolutely arbitrary in degree and duration. And if it has the power of the state behind it, the vulnerability of the victim is absolute as well. The victim's agency, his effective self, is at least for some time eliminated. The awareness of being a broken person is an extreme form of mental suffering: profound regret at what has been lost and deep despair about what may next come.

We may appear now to be launching our own attempt to perform a substitution trick. ${ }^{102}$ Above we criticized the statutes for substituting "prolonged mental harm" for "mental pain or

\footnotetext{
${ }^{101}$ MAYER, supra note 24, at 175.

${ }^{102}$ We are grateful to Stephen Nathanson for noting this possible misunderstanding.
} 
suffering." Now we are noting that severe mental pain or suffering can lead to unhinging the self-profoundly undermining the personality structure. Are we trying to suggest that severe mental pain or suffering just is an undermining of the personality structure, which would imply that apparent severe mental pain or suffering that did not succeed in unhinging the self of the victim would not count as severe mental pain or suffering? Not at all—severe mental pain or suffering remains severe mental pain and suffering; it is an awful experience undergone, not the likely damaging results of undergoing it. Not all severe mental pain or suffering leaves its victim psychologically broken. Mental torture, like physical torture, sometimes fails. The point is that breaking resistance by producing psychological regression is the contemporary rationale for mental torture and specifies the goal pursued. Mental torture that fails to attain its goal is still mental torture, and presumably no one would suggest that torture should be punished only if it succeeds. We are in effect attempting to overcome any remaining materialist bias by explaining another respect in which mental torture is extremely objectionable. Neither the means nor the end is 'subjective' in any respect that makes either in the least unreal. The collapse of a personality may be in a literal sense 'subjective,' but it is utterly real. Allowing the state to use severe mental pain or suffering is allowing them to employ an inherently awful tool-the experience of severe mental pain or suffering - that is capable sometimes of attaining an awful goal: destroying the psychological identity of its target. This technique is objectionable even when it fails and all the more so when it succeeds. And there are other reasons why mental torture must be controlled.

The infliction of physical pain was the old-fashioned and crude means of bringing merciless pressure to bear, but up-to-date and sophisticated means of pressure can involve relatively little physical pain and instead use overpowering psychological stress. Distinctively 
contemporary torture aims to break the person without breaking his bones. ${ }^{103}$ One advantage of psychological torture, then, is that it protects the torturers against being brought to justice by minimizing physical evidence.

The disadvantage is that, if anything, psychological torture is even less reliable as a method of gaining accurate information than physical torture. Consider an instructive example involving sleep deprivation:

A Prince George's [sic] County [Maryland] jury awarded \$6.38 million Thursday to a man who falsely confessed to killing his wife following 38 hours of interrogation by the Prince George's County police, according to the man's attorneys.

Keith Longtin spent more than eight months in jail after he told police he killed his wife, Donna Zinetti, in 1999 following a marathon interrogation in which he wasn't allowed to sleep. DNA evidence later exonerated Longtin and led to the arrest and conviction of a Washington, D.C., man.

Longtin's case was one of several in which the Prince George's police obtained false confessions through extensive interrogations. ${ }^{104}$

Here we have a nice experiment on reliability: a man, facing life in prison or the death penalty if convicted, who nevertheless falsely confesses to raping his own wife in the woods and slashing her face and throat 13 times. Longtin had nothing to gain and everything to lose by the confession-his liberty or life, his reputation, the respect and affection of anyone who knew

\footnotetext{
${ }^{103}$ The old and the new, the physical and the psychological, are of course often combined in fact, although the physical is still usually kept "clean," that is, leaving no permanent scars or marks. Water torture -- recently given the cute new name, "waterboarding" -- combines psychological terror and physical pain, but leave no marks. Psychological torture tends to be clean -- enhancing its "deniability" -- but not all clean torture is psychological. We are grateful to Jeremy Waldron for discussion of this point.

104 Associated Press, $\$ 6$ million awarded in false confession lawsuit, MSNBC (Aug. 31, 2006), available at http://www.msnbc.msn.com/id/14609924/ (visited Dec. 16, 2010).
} 
him—but even with all those incentives lined up against a false confession, sleep deprivation broke him down.

Once the victim's spirit is broken, he becomes desperate to please the torturer and to give him whatever the victim believes he wants. The notorious unreliability of the results of psychological torture is a predictable result of the fact that CIA "experts" copied their supposedly innovative methods of psychological torture from techniques developed by Communist regimes to induce false confessions. ${ }^{105}$ The illogic of the assumption that a method that will cause false confessions will somehow yield accurate and timely information useful in preventing terrorist attacks is stunning.

So something else wrong with psychological torture is that it could only conceivably be justified if it reliably produced useful results, but it is not generally reliable for reasons that are perfectly obvious: the victim's motivation is to please, not to provide accurate information. U.S. Army manuals have for years pointed out the unreliability of all torture. ${ }^{106}$ The fact that the spirit of the victim of psychological torture has been broken explains why he will say or do utterly anything that he guesses will please the torturer.

But the predictable unreliability of psychological torture-its failure in most cases to produce valuable information-is not the main reason for its distinctive wrongfulness. That is its mercilessness - the limitlessness of the invasion of one person by others. Psychological torture is not finished until a person is broken. Its practitioners constantly talk about "overcoming resistance" and producing "rapid regression." "Overcoming resistance” means destroying the

\footnotetext{
${ }^{105}$ Scott Shane and Mark Mazzetti, In Adopting Harsh Tactics, No Inquiry Into Past Use, N.Y. Times (Apr. 22, 2009) (noting Bush Administration unawareness that methods were partly copied from those used against American POWs in Korean War to wring false confessions).

${ }^{106}$ United States, Department of the Army, Headquarters. FM 34-52: Intelligence Interrogation 1 (Washington: Dep't of the Army, 1992), available at http://www.fas.org/irp/doddir/army/fm34-52.pdf (visited 1/28/11). This version of the Field Manual was superseded by another version in 2006.
} 
integrity of the self, eliminating the agency that is presupposed by autonomy or freedom of the will. Psychological torture literally destroys the self without destroying—and, sometimes, without even serious injuring - the physical body. The victim need not suffer any bruises or lacerations and need not lose any fingernails or sexual organs— he simply loses his self, which is "broken" so that "resistance" can be overcome.

Psychological torture employed by the state is government occupation of the human soul. It is the ultimate assertion of arbitrary state power - a kind of power that kings in the Dark Ages could only fantasize about. Interrogators in the 21 st century are living out the wildest fantasies of medieval kings. Those whose quivering souls have been occupied by government agents may wish that their bodies had been put on the rack instead. We have laws restraining the behavior of governments that have occupied the land of others, but nothing would restrain those who have seized control of others' souls, if we were to ignore psychological torture except when it both is specifically intended to cause and does in fact cause prolonged additional harm, as current U.S. law requires.

Morality is about limits—-he who will stop at nothing has no morality. A moral limit on government is the prohibition on brutality even during the exercise of coercion. Law, as noted by Jeremy Waldron, is about the exercise of power without brutality.

The prohibition on torture is expressive of an important underlying policy of the law, which we might try to capture in the following way: Law is not brutal in its operation. Law is not savage. Law does not rule through abject fear and terror, or by breaking the will of those whom it confronts. If law is forceful or coercive, it gets its way by nonbrutal methods which respect rather than mutilate the dignity and agency of those who are its subjects... They will not be herded like cattle or broken like horses; they will not 
be beaten like dumb animals or treated as bodies to be manipulated. Instead, there will be an enduring connection between the spirit of law and respect for human dignity—respect for human dignity even in extremis, where law is at its most forceful and its subjects at their most vulnerable. ${ }^{107}$

The state sometimes coerces people. This, after all, is part of the point: if we did not sometimes need an institution with the authority to coerce, we would not need any institution recognizable as a state. Brutal physical beatings can be awful, but the ultimate brutality is an assault on the integrity of the self-the elimination of the complex person that someone has over the course of his life become, and its replacement with the simple child he once was. But U.S. law does nothing to protect us from the mental pain and suffering that is the kind of torture that slick modern torturers are most likely to use against us when the state wants to control us inside as well as out.

\footnotetext{
${ }^{107}$ Jeremy Waldron, Torture and Positive Law: Jurisprudence for the White House, 105 COLUM. L. REV. (2005)
} 1681, 1726-7. 